\title{
Climatic impacts of stratospheric geoengineering with sulfate, black carbon and titania injection
}

\author{
Anthony C. Jones ${ }^{1}$, James M. Haywood ${ }^{1,2}$, and Andy Jones ${ }^{2}$ \\ ${ }^{1}$ College of Engineering Maths and Physical Sciences, University of Exeter, Exeter, UK \\ ${ }^{2}$ Met Office Hadley Centre, Exeter, UK \\ Correspondence to: Anthony C. Jones (aj247@exeter.ac.uk)
}

Received: 12 October 2015 - Published in Atmos. Chem. Phys. Discuss.: 3 November 2015

Revised: 25 February 2016 - Accepted: 26 February 2016 - Published: 4 March 2016

\begin{abstract}
In this paper, we examine the potential climatic effects of geoengineering by sulfate, black carbon and titania injection against a baseline RCP8.5 scenario. We use the HadGEM2-CCS model to simulate scenarios in which the top-of-the-atmosphere radiative imbalance due to rising greenhouse gas concentrations is offset by sufficient aerosol injection throughout the 2020-2100 period. We find that the global-mean temperature is effectively maintained at historical levels for the entirety of the period for all three aerosolinjection scenarios, though there is a wide range of sideeffects which are discussed in detail. The most prominent conclusion is that although the $\mathrm{BC}$ injection rate necessary to produce an equivalent global mean temperature response is much lower, the severity of stratospheric temperature changes $\left(>+70^{\circ} \mathrm{C}\right)$ and precipitation impacts effectively exclude $\mathrm{BC}$ from being a viable option for geoengineering. Additionally, while it has been suggested that titania would be an effective particle because of its high scattering efficiency, it also efficiently absorbs solar ultraviolet radiation producing a significant stratospheric warming $\left(>+20^{\circ} \mathrm{C}\right)$. As injection rates and climatic impacts for titania are close to those for sulfate, there appears to be little benefit in terms of climatic influence of using titania when compared to the injection of sulfur dioxide, which has the added benefit of being well-modeled through extensive research that has been carried out on naturally occurring explosive volcanic eruptions.
\end{abstract}

\section{Introduction}

The climatic impacts of continued greenhouse gas (GHG) emissions are likely to be severe which has prompted countenance of new strategies for tackling GHG-induced global warming (e.g Collins et al., 2013). Geoengineering strategies, or large-scale climate interventions that aim to reduce global warming, include strategies to sequester atmospheric carbon dioxide - carbon dioxide removal (CDR) methods, and strategies to reduce solar irradiance at Earth's surface - solar radiation management (SRM) methods (Shepherd et al., 2009). Stratospheric Aerosol Injection (SAI), an SRM scheme which has received significant attention, involves the enhancement of the stratospheric aerosol layer in order to reflect more sunlight back to space. This scheme mimics large volcanic eruptions such as Mt. Pinatubo in 1991, which injected approximately $15-20 \mathrm{Tg}$ of sulfur dioxide $\left(\mathrm{SO}_{2}\right)$ into the tropical stratosphere and induced a globally averaged surface cooling of around $-0.3{ }^{\circ} \mathrm{C}$ for the following 2 years (Stenchikov et al., 2002).

Sulfate $\left(\mathrm{SO}_{4}\right)$ aerosols have featured predominantly in SAI research because of the volcanic analogue (e.g., in the Geoengineering Model Intercomparison Project, GeoMIP, Kravitz et al., 2013). General Circulation Model (GCM) simulations suggest that, while sufficient sulfate injection could effectively reduce global-mean temperature, possible side effects include changes to regional precipitation (e.g., Bala et al., 2008; Tilmes et al., 2013), ozone (e.g., Tilmes et al., 2009; Pitari et al., 2014), stratospheric dynamics (Aquila et al., 2014) and sea-ice extent (Berdahl et al., 2014). Precipitation changes could result from changes to the moist static stability of the atmosphere and a concomitant weakening of 
the hydrological cycle (Bala et al., 2008); furthermore, the regional precipitation changes under GeoMIP simulations have been shown to be reasonably consistent across a range of climate models (Tilmes et al., 2013). Ozone concentrations could change as a result of enhanced heterogeneous chemistry on the surface of sulfate aerosols or indirectly by changes to the stratospheric dynamics and chemistry (e.g., Tilmes et al., 2009). Stratospheric dynamical changes could occur as the result of tropical heating in the sulfate layer and by changes to wave propagation from the troposphere (e.g., Aquila et al., 2014).

In order to ameliorate the known side-effects of sulfate injection, some authors have proposed alternative aerosols to sulfate (e.g., Teller et al., 1997). Crutzen (2006) suggested the possible injection of black carbon (BC), which would mimic hypothetical nuclear winter scenarios. One advantage of $\mathrm{BC}$ over sulfate is that less mass would be needed for an equivalent radiative forcing (Crutzen, 2006). BC particles efficiently absorb solar radiation, unlike sulfate which primarily reflects solar radiation (Ferraro et al., 2011). Alternatively, minerals such as titania $\left(\mathrm{TiO}_{2}\right)$, silica $\left(\mathrm{SiO}_{2}\right)$ and alumina $\left(\mathrm{Al}_{2} \mathrm{O}_{3}\right)$, which have a high refractive index at wavelengths of peak solar radiative flux $(\sim 550 \mathrm{~nm})$, have also been suggested (Pope et al., 2012). Although the use of alternative aerosols is not a new suggestion (e.g., Teller et al., 1997), comparatively little research has been conducted on their potential utility. Kravitz et al. (2012) simulated a constant $\mathrm{BC}$ injection scenario of $1 \mathrm{Tg} \mathrm{yr}^{-1}$ in the tropics for small radius $(0.03 \mu \mathrm{m})$ and large radius $(0.15 \mu \mathrm{m})$ aerosols. They found that the small particle $\mathrm{BC}$ aerosol scenario produced a global surface cooling of $-9.45^{\circ} \mathrm{C}$, but also induced stratospheric warming $>+60^{\circ} \mathrm{C}$ and global ozone loss of $50 \%$. The large particle $\mathrm{BC}$ aerosol scenario had a neglige climatic impact. Using a fixed dynamical heating (FDH) code, Ferraro et al. (2011) compared the stratospheric heating of sulfate, titania, and BC layers for an equivalent instantaneous radiative forcing. Their results showed a tropical stratospheric warming signal for all the aerosols, though much greater in the case of BC. To date, no work has used a comprehensive fully coupled atmosphere-ocean GCM to directly compare the possible climatic impacts of SAI with alternative aerosols to sulfate, which is the motivation for this research.

In this work, we simulate the stratospheric injection of sulfate, titania and BC against a baseline RCP8.5 concentrations scenario using a fully coupled GCM. Titania is selected to represent an efficient light-scattering aerosol and $\mathrm{BC}$ is selected as a light-absorbing aerosol. RCP8.5, which is the high-end carbon-intensive CMIP5 scenario, is selected to give a significant greenhouse effect against which to employ geoengineering, in order to distinguish the climatic impacts specific to each aerosol. Observations have shown that the current global GHG emissions exceed the emissions inherent in RCP8.5 (Peters et al., 2013); therefore our work could be considered as geoengineering against a business-as-usual scenario. Additionally, the next generation of GeoMIP simulations (GeoMIP6) will utilize a carbon-intensive scenario (Kravitz et al., 2015), hence our work will provide a useful supplement to those results. We chose to inject aerosol at a sufficient rate to counterbalance the Top Of the Atmosphere (TOA) global- and annual-mean caused by increasing atmospheric GHGs. Our simulation design is similar to the G3 scenario of the Geoengineering Model Intercomparison Project (GeoMIP), which instead used the RCP4.5 concentrations scenario as its baseline and injected sulfate at a sufficient rate to counterbalance GHG radiative forcing (Kravitz et al., 2011). We analyze the climate changes in the 2090s with respect to a simulated historical period and discuss impacts on a wide range of meteorological parameters.

\section{Model}

\subsection{The HadGEM2-CCS model}

For this investigation, we use the HadGEM2-CCS climate model in a fully coupled atmosphere-ocean mode. HadGEM2-CCS is the high-top configuration of the HadGEM2 family of models, and includes a well-resolved stratosphere that is capable of internally generating a realistic quasi-biennial oscillation (QBO) (The HadGEM2 Development Team, 2011). The atmosphere component comprises 60 vertical levels extending to $84 \mathrm{~km}$ and a horizontal resolution of $1.25^{\circ} \times 1.875^{\circ}$ latitude by longitude respectively. The 40-level ocean component has a horizontal resolution of $1^{\circ}$ by $1^{\circ}$ from the poles to $30^{\circ} \mathrm{N} / \mathrm{S}$, with the latitudinal resolution then increasing smoothly to $0.33^{\circ}$ at the equator (The HadGEM2 Development Team, 2011). For this investigation, GHG concentrations, stratospheric ozone, anthropogenic aerosols and aerosol precursor gases are prescribed following the Coupled Model Intercomparison Project phase 5 (CMIP5) (Taylor et al., 2012) protocol, with historical data from 1860 to 2005 and RCP8.5 concentrations from 2005 to 2100. HadGEM2-CCS contains the aerosol module Coupled Large-scale Aerosol Simulator for Studies in Climate (CLASSIC). The module's sulfur cycle is described in detail in Bellouin et al. (2011). Briefly, it includes the oxidation of sulfur dioxide $\left(\mathrm{SO}_{2}\right)$ to sulfate aerosol in aqueous and gas phase reactions. Sulfate is represented by Aitken, accumulation and dissolved modes, with hygroscopic growth in the accumulation mode following d'Almeida et al. (1991). Aerosol size modes are represented by lognormal size distributions with a prescribed dry-mode median radius $\left(r_{\mathrm{m}}\right)$ and geometric standard deviation $(\sigma)$.

\subsection{Stratospheric aerosol microphysical and optical properties}

For this investigation, stratospheric sulfate is modelled using the volc2 size-distribution from Rasch et al. (2008) for the sulfate accumulation mode, with $r_{\mathrm{m}}=0.376 \mu \mathrm{m}$ and $\sigma=$ 


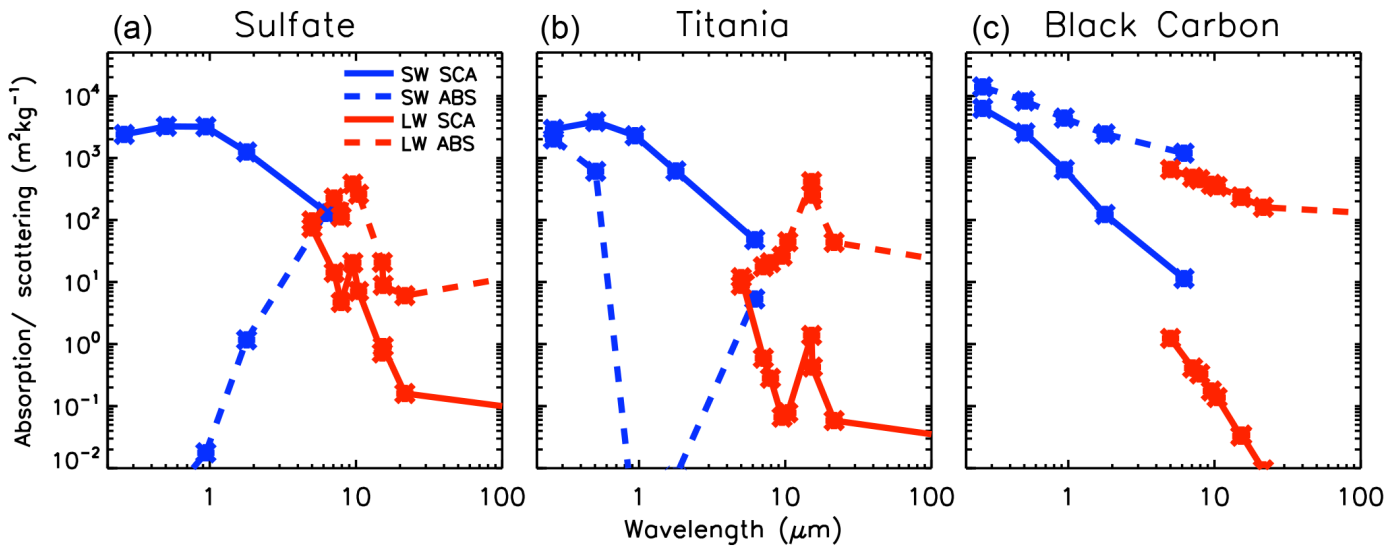

Figure 1. Optical properties as a function of wavelength for (a) accumulation-mode sulfate, (b) titania, (c) black carbon. Points are plotted at the middle of each spectral waveband, as detailed in Bellouin et al. (2007).

1.25 ; the relatively large $r_{\mathrm{m}}$ is chosen to reflect the high concentrations of $\mathrm{SO}_{2}$ injected in this experiment.

CLASSIC includes a tropospheric BC scheme with fresh, aged and in-cloud modes (Bellouin et al., 2011). We introduce an additional non-hygroscopic stratospheric BC component and prescribe a lognormal size-distribution with $r_{\mathrm{m}}=$ $0.0118 \mu \mathrm{m}$ and $\sigma=2.0$, which is taken from tropospheric BC observations (Deepak and Gerber, 1983). We prescribe a density for BC of $1000 \mathrm{~kg} \mathrm{~m}^{-3}$ and take refractive indices from a World Meteorological Organisation report (Deepak and Gerber, 1983).

For stratospheric titania, we assume the non-hygroscopic lognormal size distribution of Pope et al. (2012) with $r_{\mathrm{m}}=$ $0.045 \mu \mathrm{m}$ and $\sigma=1.8$. This size-distribution was selected to give the titania aerosol a high scattering efficiency, as shown by Pope et al. (2012). We prescribe a density for titania of $4230 \mathrm{~kg} \mathrm{~m}^{-3}$ (Pope et al., 2012), and for the refractive indices we follow Ferraro et al. (2011) and use the average of the extra-ordinary and ordinary values from Ribarsky (1985).

The specific absorption $\left(k_{\mathrm{abs}}\right)$ and scattering $\left(k_{\mathrm{sca}}\right)$ coefficients for sulfate (accumulation/dry-mode), titania and BC are plotted in Fig. 1 as a function of wavelength. For sulfate, the specific extinction coefficient $\left(k_{\mathrm{ext}}\right)$ at $500 \mathrm{~nm}$ of $3200 \mathrm{~m}^{2} \mathrm{~kg}^{-1}$ and single scattering albedo $\left(\omega_{\mathrm{o}}\right)$ of 1 reflects the non-absorbing properties of sulfate. Although titania's $500 \mathrm{~nm}$ scattering efficiency $\left(k_{\mathrm{sca}}=3850 \mathrm{~m}^{2} \mathrm{~kg}^{-1}\right)$ is greater than sulfate's in this instance, titania additionally absorbs SW radiation $\left(k_{\mathrm{abs}}=2000\right.$ at 250 , and $k_{\mathrm{abs}}=600 \mathrm{~m}^{2} \mathrm{~kg}^{-1}$ at $500 \mathrm{~nm}$ ) which can be explained by the band-theory of solids (Yang et al., 2003). Thus titania is partially absorbing. Our modelled BC efficiently absorbs SW radiation $\left(k_{\text {abs }}=8300 \mathrm{~m}^{2} \mathrm{~kg}^{-1}\right.$ at $\left.500 \mathrm{~nm}\right)$ but also produces a non-negligible SW scattering effect $\left(k_{\mathrm{sca}}=2500 \mathrm{~m}^{2} \mathrm{~kg}^{-1}\right.$ at $500 \mathrm{~nm}$ ) which is comparable in magnitude to the equivalent scattering efficiency of both titania and sulfate. Therefore, to describe titania as an efficient light-scatterer and/or BC as an efficient light-absorber is an over-simplification.
Our choice of particle size and density will impact the aerosol's gravitational sedimentation rate and therefore its atmospheric residence time (the sedimentation rate is also a property of the local atmospheric conditions) (Rasch et al., 2008). To determine the importance of our choice of aerosol properties, we have calculated the respective gravitational sedimentation rates by using the method of Pruppacher and Klett (1979) (which utilizes Stoke's law) and incorporating temperature and pressure values from the International Standard Atmosphere (ICAO, 1993) (Fig. S1 in the Supplement). We find that the average sedimentation rates between 18 and $26 \mathrm{~km}$ altitude for our prescribed sulfate, titania, and $\mathrm{BC}$ are $23,9.5$ and $0.75 \mathrm{~m} \mathrm{day}^{-1}$, respectively, and the equivalent rates between 26 and $30 \mathrm{~km}$ are 52,22 , and $1.8 \mathrm{~m} \mathrm{day}^{-1}$. Therefore, one would expect $\mathrm{BC}$ to be advected to much higher altitudes than sulfate in these simulations. For perspective, Schoeberl et al. (2008) deduced from observations that the atmospheric tropical vertical velocity between $18-26 \mathrm{~km}$ has an upper limit of $35 \mathrm{~m} \mathrm{day}^{-1}$, and the equivalent velocity between 26 and $30 \mathrm{~km}$ is below $61 \mathrm{~m} \mathrm{day}^{-1}$.

\section{Method}

We first validated the model's stratospheric sulfate scheme by simulating the Mt Pinatubo eruption and then comparing the results with observations. These simulations comprised a 10 -member ensemble in which $20 \mathrm{Tg}\left(\mathrm{SO}_{2}\right)$ is injected between 16 and $18 \mathrm{~km}$ over a single day in June 1991, following the method of Aquila et al. (2012). Figure 2a shows the global- and annual-mean sulfate aerosol optical depth (AOD) anomaly for the HadGEM2-ensemble and for AVHRR and SAGE-II observations. The model clearly captures the peak AOD from the AVHRR data, and the exponential decline thereafter. Figure $2 \mathrm{~b}-\mathrm{d}$ show the zonal-mean AOD anomaly for the same time period. The agreement between the model and observed AOD is reasonable. Some dif- 

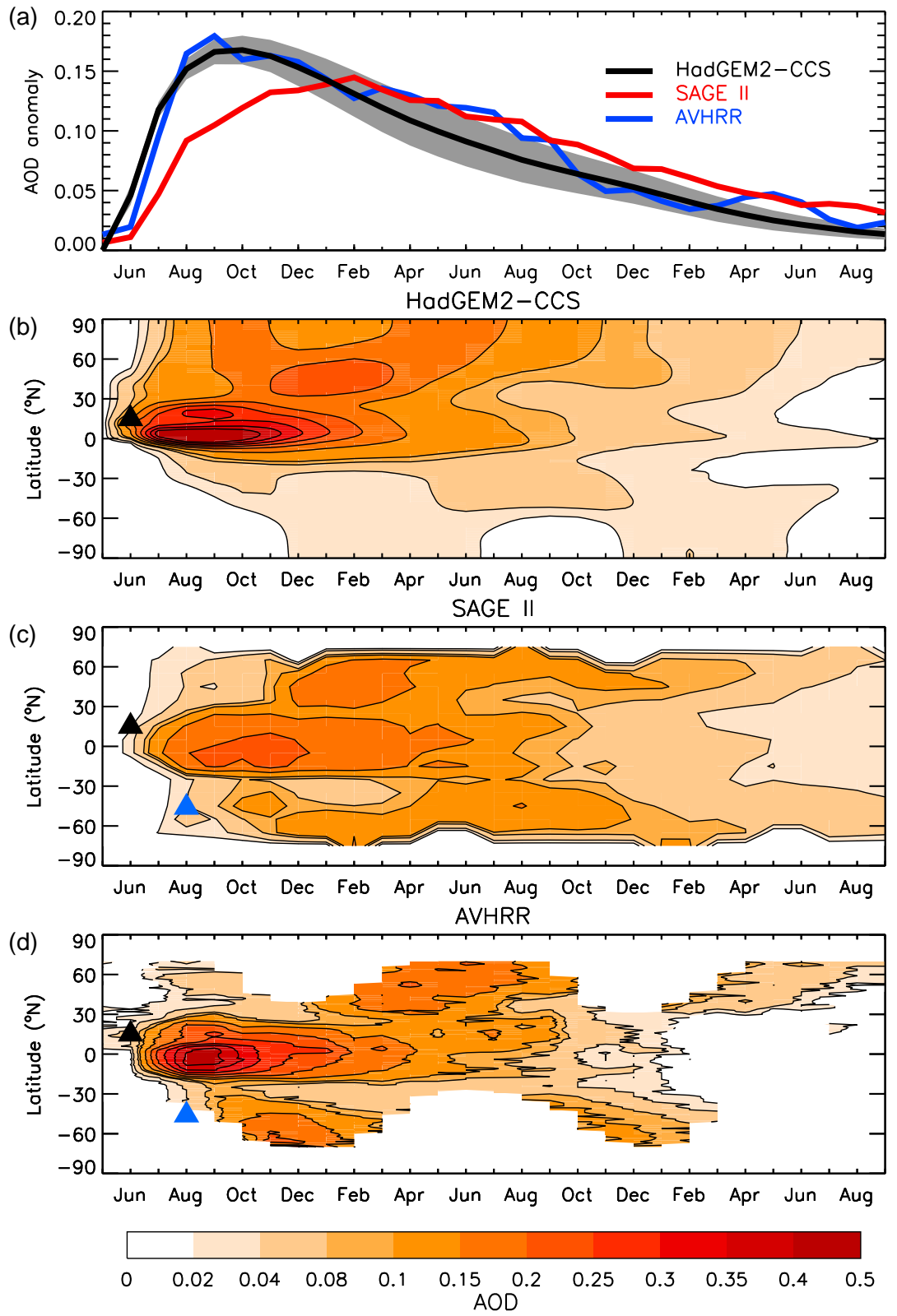

Figure 2. (a) $75^{\circ} \mathrm{S}-75^{\circ} \mathrm{N}$-mean $550 \mathrm{~nm}$ sulfate AOD anomaly for the Pinatubo simulations and observations, (b-d) time series of zonalmean $550 \mathrm{~nm}$ sulfate AOD anomaly.

ferences in the temporal evolution of the AODs in the model and the observations are due to the almost concurrent eruption of Cerro Hudson which injected approximately $3.3 \mathrm{Tg}$ $\left(\mathrm{SO}_{2}\right)$ into the Southern Hemisphere (Deshler and AndersonSprecher, 2006). This relatively close agreement between observations and HadGEM2 estimates, together with other modeling studies of other volcanic eruptions (Haywood et al., 2010) suggests that the model is a useful tool for stratospheric geoengineering simulations.

The geoengineering investigation was based on a 240-year pre-industrial control simulation (forced by constant 1860s
GHGs and aerosol emissions) and historical simulations for the period 1860-2005 following CMIP5 (Taylor et al., 2012) protocol followed by RCP8.5 emission specified from 2005 to 2019. Leading on from these simulations, we performed 3-member ensembles for the period 2020-2100 for RCP8.5 only, RCP8.5 with $\mathrm{SO}_{2}$ injection (geoSulf), RCP8.5 with $\mathrm{TiO}_{2}$ injection $\left(\mathrm{geoTiO}_{2}\right)$, and $\mathrm{RCP} 8.5$ with $\mathrm{BC}$ injection (geoBC). Aerosol (or gaseous $\mathrm{SO}_{2}$ for the geoSulf scenario) was injected at a constant rate between 23 and $28 \mathrm{~km}$ altitude in a single vertical column at the equator. The injection altitude and location were chosen to ensure a long stratospheric 
(a)

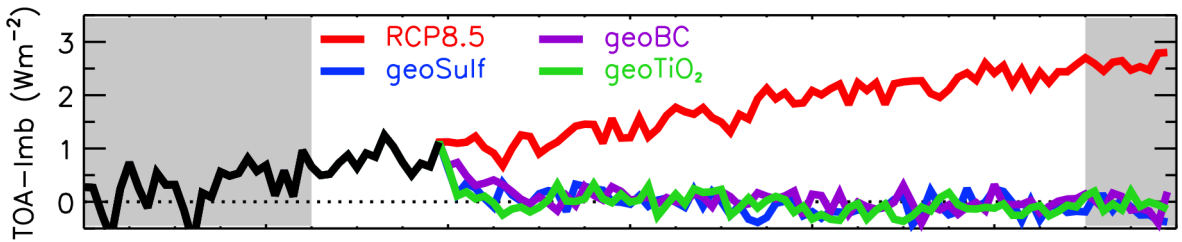

(b)

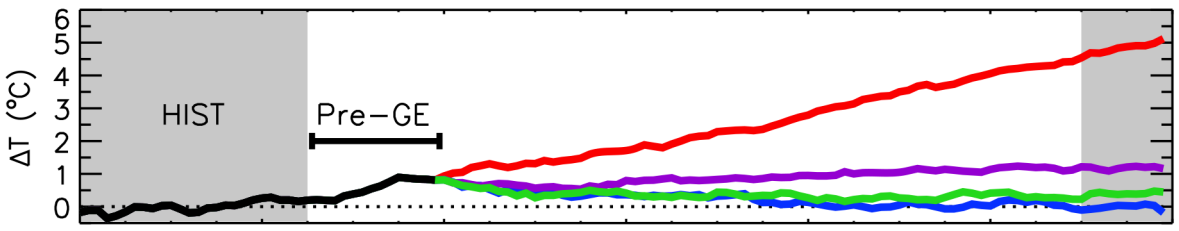

(c)

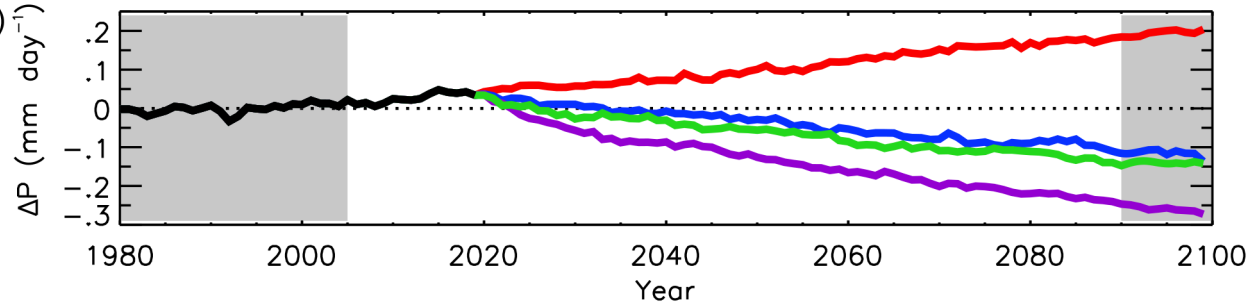

Figure 3. Time series of annual/global-mean (a) top-of-the-atmosphere radiative flux anomaly with respect to the pre-industrial control simulation, (b) near-surface air temperature anomaly with respect to the HIST period, (c) global mean precipitation anomaly with respect to HIST.

lifetime of the aerosol, which is transported poleward by the upper branch of the Brewer-Dobson circulation (Niemeier et al., 2011), and therefore make the geoengineering approach reasonably efficient.

We inject aerosol at such a rate as to maintain the topof-the-atmosphere (TOA) net radiative flux at piControl levels. Specifically, we define the TOA radiative flux Imbalance (TOA-Imb) as the global- and annual-mean TOA net radiative flux (incoming SW minus outgoing $\mathrm{LW}+\mathrm{SW}$ ) minus the average TOA net radiative flux of the piControl period. The piControl TOA net radiative flux is positive $\left(+0.27 \mathrm{~W} \mathrm{~m}^{-2}\right)$ as anthropogenic GHGs were emitted prior to 1860 (the piControl reference period). By sufficient aerosol injection, we aim to maintain TOA-Imb $=0$. This scenario represents our interpretation of "equal amount of geoengineering" for each aerosol. The advantage of returning net radiation to piControl levels (rather than completely equilibrating TOA fluxes) is that piControl had already been simulated comprehensively for CMIP5 (240 model years), hence permitting robust statistics to be calculated. The TOA radiative imbalance is a metric that satellites are able to measure (e.g., CERES, L'Ecuyer et al., 2015 and EarthCare, Illingworth et al., 2015), albeit with $\pm 3 \mathrm{~W} \mathrm{~m}^{-2}$ accuracy at present (Priestley et al, 2011; von Schuckmann et al., 2016). Therefore our target could be applicable to an actual SAI scenario. In contrast, adjusted Radiative Forcing (RF) (the net radiation perturbation at the tropopause from some external forcing, after stratospheric adjustment), cannot be directly measured by satellites and therefore it would be difficult to obtain a specified radiative forcing in an actual SAI scenario.
Of course, other metrics could be chosen (e.g., MacMartin et al., 2013), with each metric having its own signal and noise characteristic.

To determine the injection rates required to maintain TOAImb balance, we first conducted 15-year atmosphere-only simulations of $1 \mathrm{Tg}$ aerosol (or $\mathrm{SO}_{2}$ for sulfate) injection per year to calculate the specific radiative effect for each aerosol. We then used the radiative effect to calculate the injection rate necessary to offset the RCP8.5 anthropogenic radiative forcing (ARF) for the 2020-2100 period (with ARF values from Meinshausen et al., 2011). We used the ARF to estimate the injection rates required to produce TOA-Imb $=0$ as this seemed a sensible method for approximating the necessary aerosol injection. As the geoengineering simulations progressed, we altered the injection rate when necessary to ensure that TOA-Imb balance was maintained (Fig. S2). This feedback-orientated method is similar to the methods suggested by MacMartin et al. (2014) and Kravitz et al. (2014). A detailed description of our methods is provided in the Supplement (Sect. S2).

Our analysis focuses initially on the temporal evolution of the TOA-Imb and global mean temperature changes to show that our simulations provide plausible counterbalances to global mean temperature changes under RCP8.5. However, our main focus is on the differences between a recent historical period (1980-2005) (hereafter denoted HIST) and the geoengineering experiments during the period 2090-2100, with an emphasis on different geographical patterns. As we were not explicitly attempting to reach a specific global mean temperature, the choice of reference period was left until af- 
ter the geoengineering simulations had been completed. We then selected a recent historical period from which the 2090s global-mean temperature anomaly for geoSulf was negligible (Fig. 3b). The HIST period selected is close to the historical control period used in the IPCC AR5 report (1986-2005) (e.g., Fig. 12.10 from Collins et al., 2013) which facilitates comparison of our RCP8.5 climate changes with the CMIP5 multi-model means.

\section{Results}

\subsection{Effectiveness at maintaining global mean TOA-Imb and near-surface temperature}

Figure 3 shows the global- and annual-mean TOA-Imb and near-surface air temperature anomaly for the geoengineering and RCP8.5 simulations, with respect to the HIST period. For all of the geoengineering simulations we were able to maintain TOA-Imb $\approx 0$ for the entirety of the 80 -year period (Fig. 3a). For geoSulf, geoTiO 2 and geoBC, the TOA-Imb was maintained within $\pm 0.21, \pm 0.18$ and $\pm 0.20 \mathrm{Wm}^{-2}$, respectively ( 1 standard deviation throughout the 2020-2100 period).

The near-surface global temperature response differs between the aerosols with a greater cooling trend for sulfate than for titania or BC (Fig. 3b). To determine the cause of the anomalous warming in geoBC, we assess the net radiative flux at the top of the atmosphere for 2020-2100. Figure S3 in the Supplement shows the global-mean net-downward radiative flux anomaly for the geoengineering experiments, evaluated at the TOA and the tropopause; and the global-mean net-downward heat flux anomaly at the surface. The radiative flux changes at the TOA and tropopause, and the heat flux anomaly at the surface, are comparable for the geoSulf and geoTiO 2 experiments for the duration of 2020-2100. In contrast, geoBC exhibits an increasingly positive net radiative flux anomaly at the tropopause $\left(+0.2 \mathrm{~W} \mathrm{~m}^{-2}\right.$ averaged over 2020-2100), despite the negligible TOA radiative flux anomaly. After stratospheric temperature adjustment, radiative perturbations at the TOA and tropopause are equal for a given climate forcing, which implies that the consistently non-adjusted stratosphere (due primarily to increasing aerosol injection rates) is responsible for the differences in TOA and tropopause radiative perturbations in geoBC. Hansen et al. (1997) also found that instantaneous and adjusted radiative forcing differ most when there is a large heating affecting the tropopause. This implies that if we had injected aerosol sufficiently to produce an equal radiative effect at the tropopause, the temperature trends for the geoengineering experiments in Fig. 3 would have been more comparable. If we were to choose stabilization of temperature as our basic metric, then one could approximate the results by simply scaling the results by the ratio of the temperature perturbation relative to $1980-2005$ to that for geoSulf. The scaling would be 1 (by design) for geoSulf, 1.1 for geoTiO and 1.28 for geoBC. If the metric chosen were instead to keep the global mean precipitation the same, then the scaling would be 1 (by design) for geoSulf, 0.91 for geoTiO and 0.68 for geoBC. However, we shall see that the changes in many of the variables we consider are dominated by largescale changes in the spatial patterns of response rather than the 10-30\% changes in magnitude of the response that applying such a scaling would induce. We therefore choose to present un-scaled results here but beware that such a scaling could be applied should we wish to apply a different metric. From Fig. 3b, geoSulf exhibits a near-surface air cooling trend with respect to 2020 despite a net gain of atmospheric energy, which is likely due to an uneven vertical distribution of this energy gain.

Figure $3 \mathrm{c}$ shows the global mean precipitation anomaly with respect to the HIST period. The precipitation reduction is greater for $\mathrm{BC}$ than for sulfate and titania, despite the positive temperature trend in geoBC (Fig. 3b). The hydrological sensitivity to geoengineering, defined as the global mean precipitation change per unit temperature change, is $2 \%$ for sulfate, $2.5 \%$ for titania, and $4.6 \%{ }^{\circ} \mathrm{C}^{-1}$ for $\mathrm{BC}$. The hydrological sensitivity for RCP8.5 is $1.32 \%{ }^{\circ} \mathrm{C}^{-1}$, which is close to the CMIP5 ensemble-mean (Fig. 12.7 from Collins et al., 2013). For comparison, Bala et al. (2008) found a hydrological sensitivity of 2.4 for solar irradiance reduction and $1.4 \%{ }^{\circ} \mathrm{C}^{-1}$ for $\mathrm{CO}_{2}$ increase.

\subsection{Aerosol distribution}

The time-averaged injection rates for the 2090s period are $14 \mathrm{Tg}\left(\mathrm{SO}_{2}\right), 5.8$ and $0.81 \mathrm{Tg} \mathrm{yr}^{-1}$ for geoSulf, geoTiO and geoBC, respectively. This $\mathrm{SO}_{2}$ injection rate is approximately equivalent to $1 \mathrm{Mt}$ Pinatubo eruption per year (Dhomse et al., 2014). These injection rates equate to global aerosol mass-burden anomalies of 49.5, 20.2, and $5.1 \mathrm{Tg}$ for geoSulf, geoTiO ${ }_{2}$ and geoBC, respectively. The geoBC mass burden is comparable to the equilibrium burdens of the high-altitude (HA) and small-radius (SmR) experiments from Kravitz et al. (2012), although they injected BC at a constant rate of $1 \mathrm{Tg} \mathrm{yr}^{-1}$, around $20 \%$ higher than in our study. Their SmR experiment involved a 10 -year injection of BC particles with a uniform radius of $0.0 \mu \mathrm{m}$, into a region between 100 and $150 \mathrm{mb}$ altitude and over the latitude range $10^{\circ} \mathrm{S}-10^{\circ} \mathrm{N}$, against baseline perpetual year 2000 conditions. Figure 4 shows the 2090s annual, June-July-August (JJA) and December-January-February (DJF) aerosol mass concentration anomalies (annual mean aerosol optical depths are shown in Fig. S4). Peak sulfate concentrations are found at the injection region at the equator (Fig. $4 \mathrm{a}, \mathrm{d}, \mathrm{g}$ ) and over the winter pole. Titania and $\mathrm{BC}$ reach greater altitudes than sulfate $(>50 \mathrm{~km})$, which is due to their smaller sizedistributions and self-lofting from SW absorption (Kravitz et al., 2012). While sulfate aerosol concentrations are highest at the equator, the highest concentrations of $\mathrm{BC}$ are found in the 

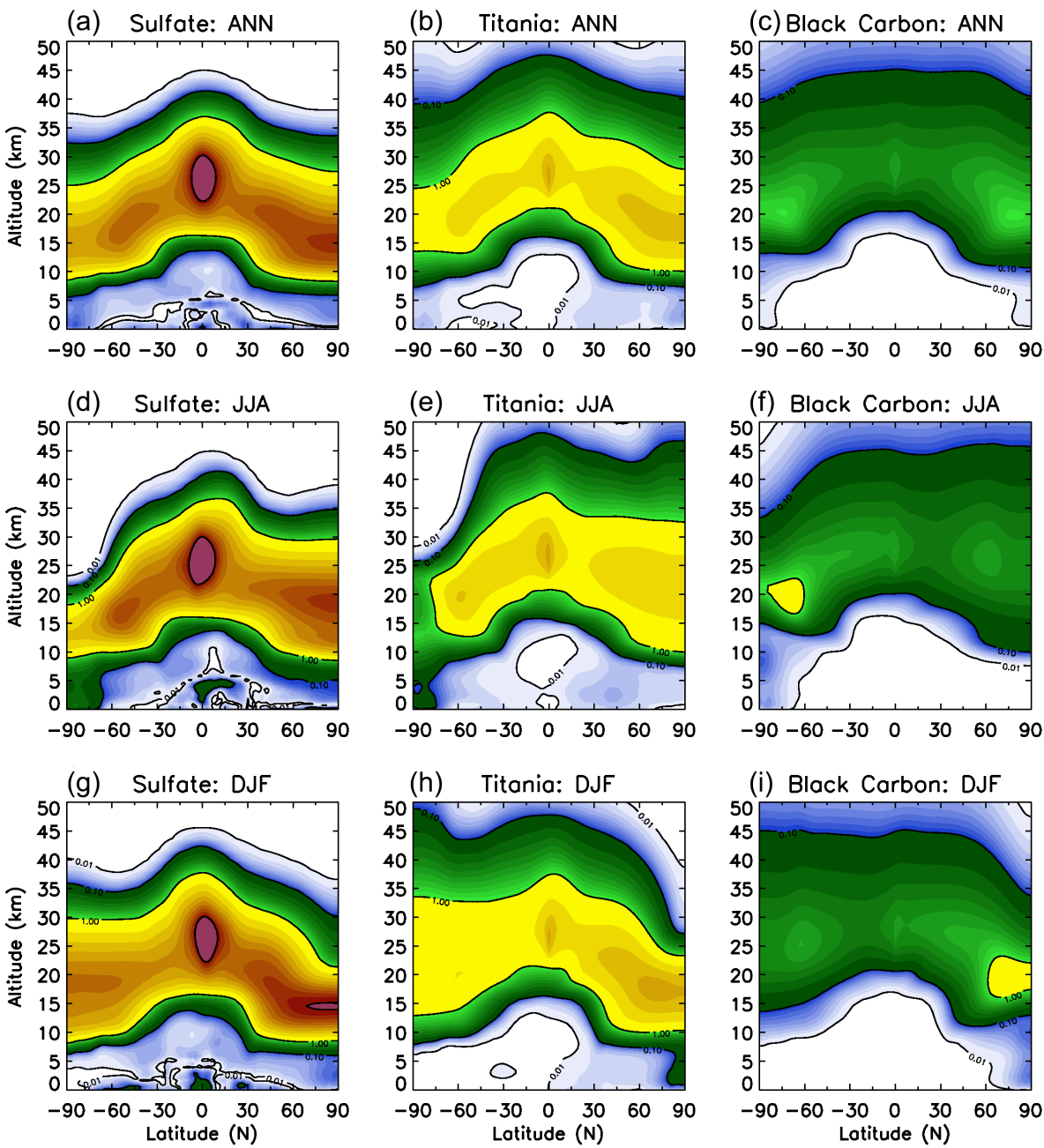

(h) Titania: DJF

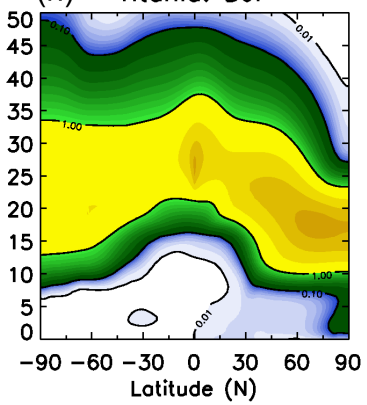

(i) Black Carbon: DJF

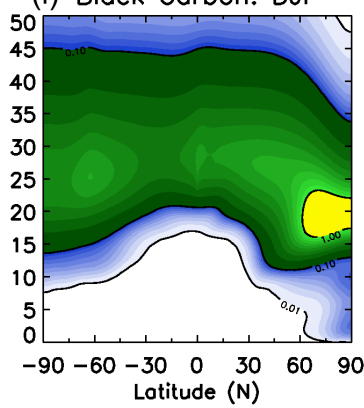

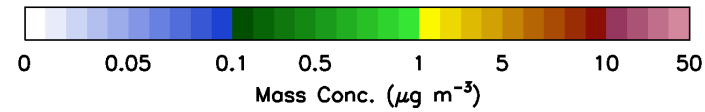

Figure 4. Annual and seasonal zonal-mean mass concentration anomalies for sulfate (geoSulf-left), titania (geoTiO 2 -center) and black carbon (geoBC - right).

polar stratosphere. This is because the larger particle size of the sulfate aerosol is subject to a larger sedimentation velocity (Fig. S1) and thus a greater fraction of aerosol is removed close to the source region. The results from titania suggest a spatial distribution intermediate between sulfate and $\mathrm{BC}$ owing to the intermediate size distribution.

Figure 5 shows the total annual, JJA and DJF aerosol deposition anomalies averaged over the 2090s (the seasonal cycle of the deposition anomalies are shown in Fig. S5). Sulfate is predominantly deposited in the Northern Hemisphere $(\mathrm{NH})$ extratropics in the boreal spring and summer (Fig. 5d), which is likely attributable to tropopause fold events in the lower branch of the Brewer-Dobson circulation (BDC) (Kravitz et al., 2012). In contrast, Titania and BC are primarily deposited at high latitudes in the polar winter, which is attributable to the diabatic descent of air in the deep branch of the BDC (e.g., Tegtmeier et al., 2008). Kravitz et al. (2012) also found in their SmR experiment that BC deposition was limited to the polar regions, but their maximum deposition was during polar summer rather than polar winter. The global- and annual-mean deposition rates of sulfate and $\mathrm{BC}$ from geoengineering are 37 and $1.5 \mathrm{mg} \mathrm{m}^{-2} \mathrm{yr}^{-1}$, respectively. These amounts may be compared with 231 and $12.7 \mathrm{mg} \mathrm{m}^{-2} \mathrm{yr}^{-1}$ from non-geoengineering sources, amounting to increases of 16 and $12 \%$, respectively. The global- and annual-mean deposition rate for titania is $11 \mathrm{mg} \mathrm{m}^{-2} \mathrm{yr}^{-1}$.

\subsection{Temperature and precipitation}

Figure 6 shows the annual mean near-surface air temperature (Fig. 6a-d) and precipitation anomalies (Fig. 6e-h) with 

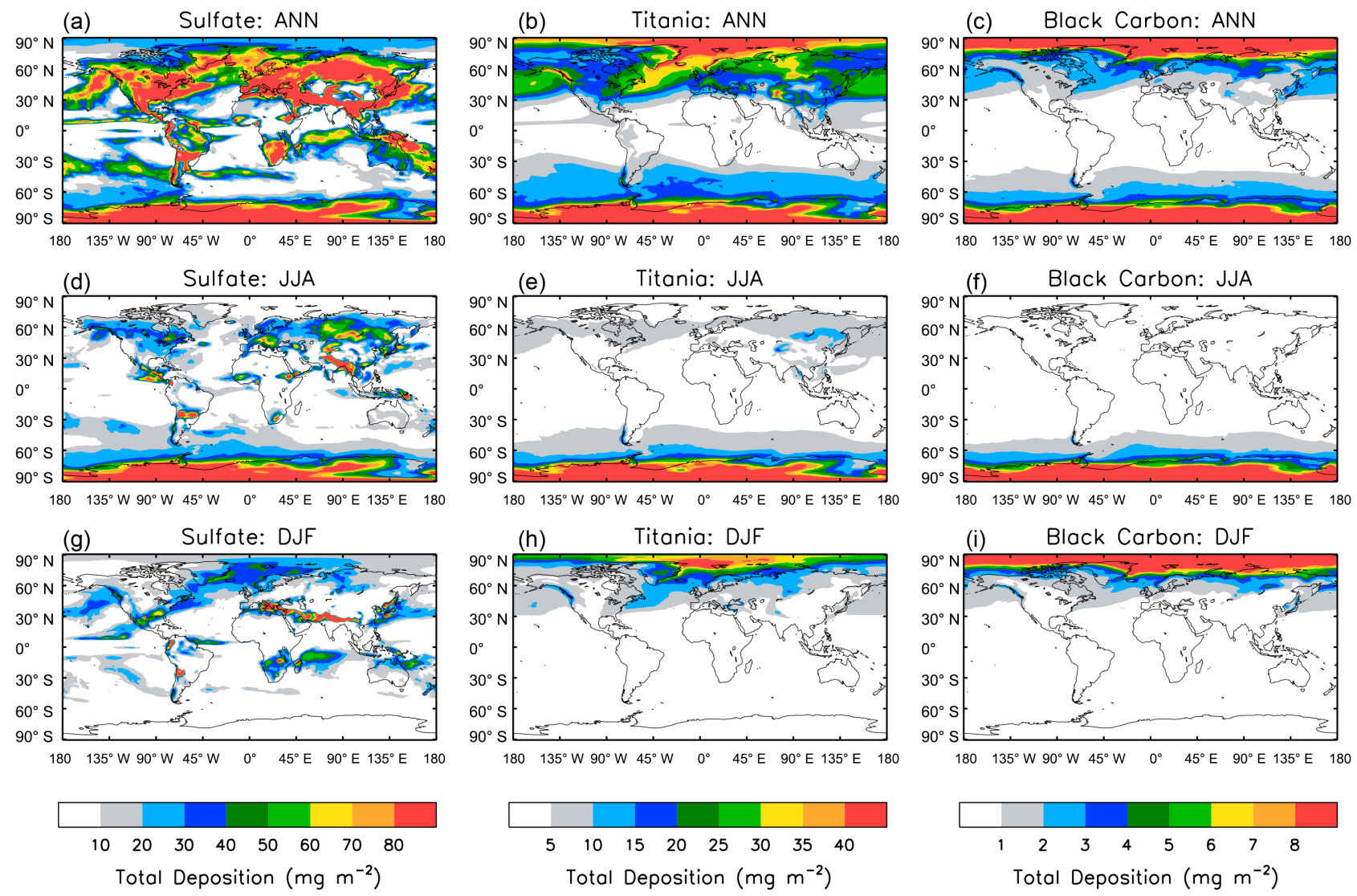

Figure 5. Annual and seasonal total deposition anomalies (in units of $\mathrm{mg} \mathrm{m}^{-2} \mathrm{yr}^{-1}$ and $0.25 \times \mathrm{mg} \mathrm{m}^{-2} \mathrm{yr}^{-1}$, respectively).

respect to HIST. RCP8.5 (Fig. 6a) shows the typical global warming signal of amplified warming at high latitudes due to temperature feedbacks (Pithan and Mauritsen, 2014) and the surface-albedo feedback (e.g., Kharin et al., 2013). This results in an annual mean warming of $+11.3^{\circ} \mathrm{C}$ averaged over the Arctic region $\left(>60^{\circ} \mathrm{N}\right)$ and an average $\mathrm{NH}$ land warming of $+7.3^{\circ} \mathrm{C}$. This figure provides an alarming picture of the change in global mean temperature by the end of this century should global society follow the RCP8.5 (essentially a business as usual) pathway. All three SAI experiments produce a surface-cooling with respect to RCP8.5, with geoSulf exhibiting the greatest global-mean cooling effect of $-4.85^{\circ} \mathrm{C}$, considering TOA-Imb is balanced for each geoengineering experiment. The latitudinal distribution of cooling varies markedly between the SAI experiments, with relative tropical cooling for geoSulf and geoTiO 2 (Fig. 6b, d) and polar cooling for geoBC (Fig. 6c). Defining the "SAI cooling effect" as the temperature difference between SAI and RCP8.5, the ratio of cooling effect at high latitudes $\left(>60^{\circ}\right)$ between geoBC and geoSulf is 1.19 and between geoBC and geoTiO ${ }_{2}$ is 1.23 . In the tropics and mid-latitudes $\left(<60^{\circ}\right)$ the equivalent ratios are 0.64 and 0.71 , respectively. The high-latitude cooling in the case of geoBC is attributable to the zonal distribution of $\mathrm{BC}$ (Fig. 4c, f, i), which is more evenly spread over the stratosphere than for geoSulf and geoTiO ${ }_{2}$. The result is a greater surface SW forcing at highlatitudes in the summer hemisphere for geoBC. For instance, in the Arctic $\left(>60^{\circ} \mathrm{N}\right)$ in JJA, the surface SW forcing is -25.65 in geoBC and -3.3 and $-6.55 \mathrm{Wm}^{-2}$ in geoSulf and geoTiO 2 , respectively. Although the global-mean precipitation rate increases for the RCP8.5 scenario (Fig. 6e), certain regions such as the Amazon basin exhibit a drying trend. This is in line with the CMIP5 multi-model projections documented in the Intergovernmental Panel on Climate Change 5th assessment report (IPCC AR5) (e.g., Fig. 12.10 from Collins et al., 2013). All of the SAI experiments show a global-mean precipitation reduction with respect to both HIST and RCP8.5 (Fig. 6f-h), which is due to the deceleration of the hydrological cycle and is a robust model response to SAI (e.g., Yu et al., 2015; Tilmes et al., 2013; Bala et al., 2008). The magnitude of the precipitation changes are greater for geoBC than for geoSulf or geoTiO ${ }_{2}$; for instance, the global mean precipitation anomaly is -0.26 for geoBC compared to -0.12 for geoSulf and $-0.14 \mathrm{~mm}$ day $^{-1}$ for geoTiO $_{2}$. In order to maintain TOA-Imb $=0, \mathrm{BC}$ must produce a greater $\mathrm{SW}$ perturbation at the tropopause and at the TOA than sulfate or titania, which is compensated by the increased LW perturbation resulting from stratospheric warm- 
(a)
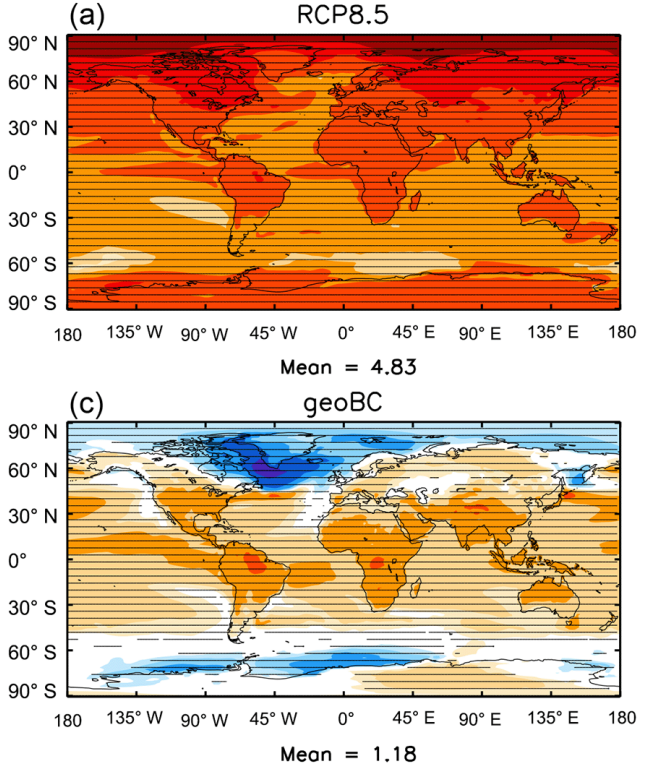

(b)

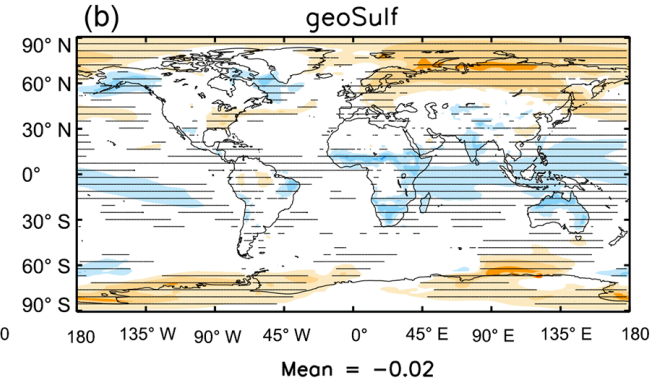

(d) geoTiO $_{2}$

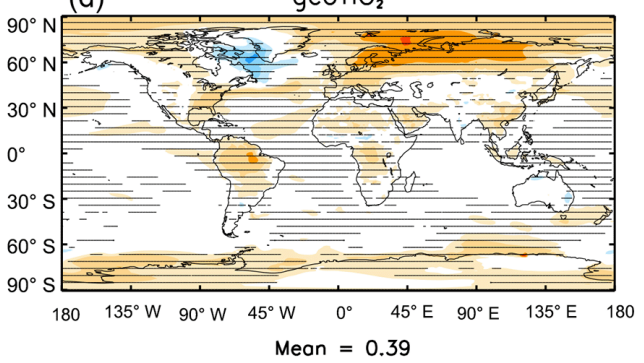

ANN

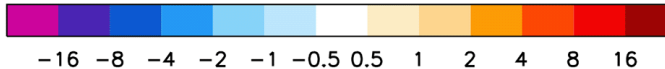

$\Delta T\left({ }^{\circ} \mathrm{C}\right)$

(e)

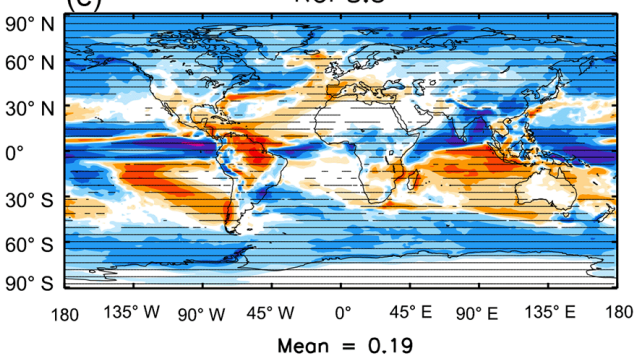

geoBC

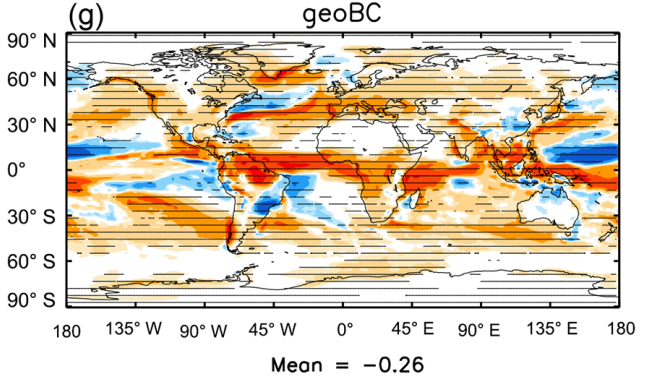

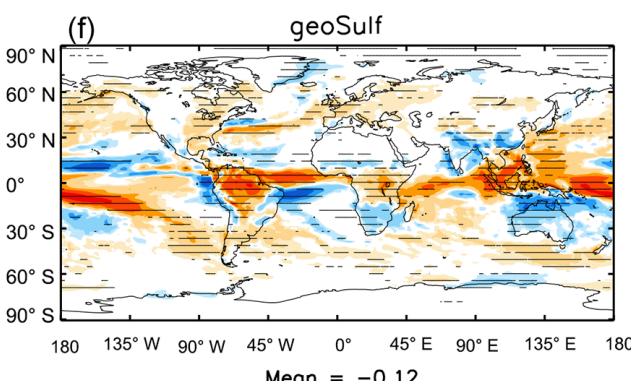

$\mathrm{geoTiO}_{2}$

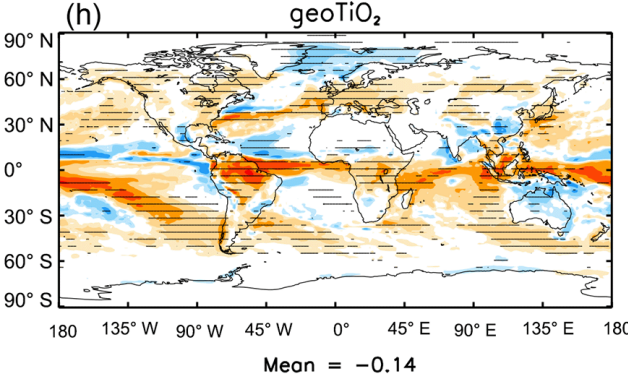

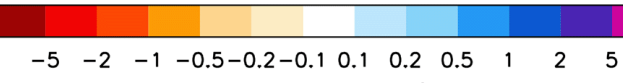

$\Delta \mathrm{P}\left(\mathrm{mm} \mathrm{day}^{-1}\right)$

Figure 6. Annual-mean near-surface air temperature (top) and precipitation rate (bottom) anomalies with respect to HIST. Stippling indicates where changes are significant at the $5 \%$ level using a two-tailed Student's $t$ test.

ing. The troposphere is relatively transparent to SW radiation but absorbs efficiently in the LW spectrum, therefore the annual-mean surface radiative forcing in the geoBC experiment is greater $\left(-18.6 \mathrm{~W} \mathrm{~m}^{-2}\right)$ than for geoSulf or geoTiO $\left(-7.4\right.$ and $-9.6 \mathrm{~W} \mathrm{~m}^{-2}$, respectively - see Fig. S6). Bala et al. (2008) and Muller and O'Gorman. (2011) have shown that the magnitude of the global-mean precipitation response to an imposed forcing is dependent on the energy flux entering and leaving the atmosphere (the radiative forcing of the atmosphere). The radiative forcing of the atmosphere is the difference between net radiative fluxes at the TOA and at the surface. As the net radiative flux anomaly at the TOA 
is, by design, equal for the different geoengineering scenarios here and the net radiative flux anomaly at the surface is greater for geoBC (Fig. S6), the precipitation reduction is therefore amplified in the geoBC scenario. It is important to note that if the RCP8.5 warming relative to HIST was completely offset in the geoBC and geoTiO 2 experiments, the hydrological response would be greater than in Fig. 6. Using the hydrological sensitivities calculated in Sect. 4.1, the precipitation changes relative to HIST would be -0.34 for geoBC and $-0.16 \mathrm{~mm} \mathrm{day}^{-1}$ for geoTiO ${ }_{2}$. From Fig. S6, the reduction in surface SW flux in the RCP8.5 scenario is due to increases in water vapor (Haywood et al., 2011). Haywood et al. (2011) report a clear-sky reduction of $-5.7 \mathrm{~W} \mathrm{~m}^{-2}$ while our study is consistent at a value of $-5.4 \mathrm{~W} \mathrm{~m}^{-2}$ (not plotted). However, in all geoengineering cases, this reduction is comprehensively overwhelmed by aerosol direct effects.

Figure 7 shows the JJA temperature (Fig. 7a-d) and precipitation (Fig. 7e-h) anomalies. In the geoSulf and geoTiO scenarios, the temperature is effectively maintained at HIST levels (Fig. 7b, d). However, a slight bias towards highlatitude $\mathrm{NH}$ warming in geoSulf and geoTiO 2 results in a northward displacement of the Inter-Tropical Convergence Zone (ITCZ), which is exemplified by the Sahelian precipitation increase in Fig. 7f, h. This phenomenon was noted by Haywood et al. (2013) and has been observed after large hemispherically asymmetric volcanic eruptions (Oman et al., 2006). Although the general pattern of precipitation change is similar for the three SAI scenarios, geoBC again displays a greater drying signal, with $80 \%$ of the total land area experiencing a JJA precipitation reduction in geoBC compared to 70 for geoTiO $_{2}, 57$ for geoSulf and $52 \%$ for RCP8.5.

Figure 8 shows the DJF temperature (Fig. 8a-d) and precipitation (Fig. 8e-h) anomalies. The temperature reduction over Greenland in geoBC (Fig. 8c) is due to the significant decrease in downwelling SW radiation at the surface during the Arctic sea-ice formation season (September-OctoberNovember), which leads to a positive sea-ice albedo feedback and further localized cooling. This inference is corroborated by Fig. 9, which shows the Arctic DJF sea-ice extent in terms of the average DJF sea-ice boundary (the Antarctic DJF sea-ice extent is shown in Fig. S7). The seaice boundary in geoBC (Fig. 9c) extends to well below Greenland, and the total sea-ice extent anomaly is +1.72 million $\mathrm{km}^{2}$ which vastly exceeds the HIST standard deviation of \pm 0.52 million $\mathrm{km}^{2}$. In comparison, the sea-ice extent anomaly of -11 million $\mathrm{km}^{2}$ for RCP8.5 (Fig. 9a) marks a reduction by $43 \%$ of the total HIST sea-ice extent. Returning to Fig. 8, the poleward shift in the $\mathrm{NH}$ extratropical rainbelt over the Atlantic in RCP8.5 (Fig. 8e) is a robust result of GHG-induced global warming and is related to storm track displacement (Lombardo et al., 2015). This same response is evident in the geoengineering simulations (Fig. 8f-h), although to a much lesser extent in geoSulf and geoTiO ${ }_{2}$.

\subsection{Stratospheric changes}

Figure 10 shows the zonal-mean temperature change as a function of latitude and altitude for the JJA and DJF seasons. The stratospheric cooling in conjunction with tropospheric warming in RCP8.5 (Fig. 10a, e) is a robust result of increasing GHG-concentrations (e.g., Schmidt et al., 2013). Aerosols directly affect temperature by absorbing radiation, and indirectly by scattering radiation and by ambient dynamical and chemical changes (Carslaw and Kärcher, 2006). Sulfate predominantly absorbs in the LW and near-infrared spectrum (Fig. 1a). The stratospheric radiative heating in geoSulf is most pronounced in the tropical region, where sulfate absorbs outgoing LW radiation from the warm troposphere below, and then emits comparatively less radiation from the ambient cold stratosphere (Ferraro et al., 2011). In contrast, titania and BC absorb in both the SW and LW spectrum (Fig. 1b, c), and therefore preferentially warm the summer-hemisphere and tropical stratosphere, where solar radiation is most prevalent. geoBC produces the most significant warming effect, with an average stratospheric (15$50 \mathrm{~km}$ altitude) temperature increase of $+33^{\circ} \mathrm{C}$ and a maximum temperature increase of $+68^{\circ} \mathrm{C}$, which occurs in JJA (Fig. 10c, g). The maximum $\mathrm{BC}$-induced heating relative to the baseline RCP8.5 scenario is $+76^{\circ} \mathrm{C}$ (Fig. S8), which is comparable to the $\sim 80^{\circ} \mathrm{C}$ temperature change Kravitz et al. (2012) found in their SmR scenario. For comparison, the maximum sulfate-induced and titania-induced heating relative to RCP8.5 are far more modest at +7 and $+22^{\circ} \mathrm{C}$, respectively.

A warming of the lower tropical stratosphere could have multiple climatic repercussions such as a weakening of the tropospheric tropical circulation (Ferraro et al., 2014), strengthening of the polar vortex (Driscoll et al., 2012) and modification of the QBO (Aquila et al., 2014). Additionally, an increase in the Tropical Tropopause Layer (TTL) temperature would increase the specific humidity of air entering the stratosphere (Dessler et al., 2013). Changes to the stratospheric water vapor content could have significant chemical and radiative impacts, contributing to ozone depletion via the $\mathrm{HO}_{x}$ cycle and stratospheric warming via LW-absorption (Kravitz et al., 2012). To assess the effects of geoengineering on stratospheric water vapor, we calculate the time-averaged $\mathrm{H}_{2} \mathrm{O}$ mixing ratio averaged between $20^{\circ} \mathrm{S}-20^{\circ} \mathrm{N}$ and $16-$ $20 \mathrm{~km}$ altitude. In the HIST era, the $\mathrm{H}_{2} \mathrm{O}$ MMR is $4.2 \mathrm{ppmv}$, in close agreement with HALOE observations (Gettelman et al., 2010). In the 2090s, the average $\mathrm{H}_{2} \mathrm{O}$ MMR is 6.3 for RCP8.5, 4.8 for geoSulf, 7.1 for geoTiO 2 , and 32.7 ppmv for geoBC. The stratospheric water vapor feedback is therefore greater for geoBC and geoTiO2 than for geoSulf.

A strengthening of the polar vortex could be instigated by an increased temperature gradient between the tropical and mid-latitude and polar stratospheres, a phenomenon which was observed after the Pinatubo eruption (Stenchikov et al., 2002). We concentrate on the Arctic wintertime (DJF) re- 

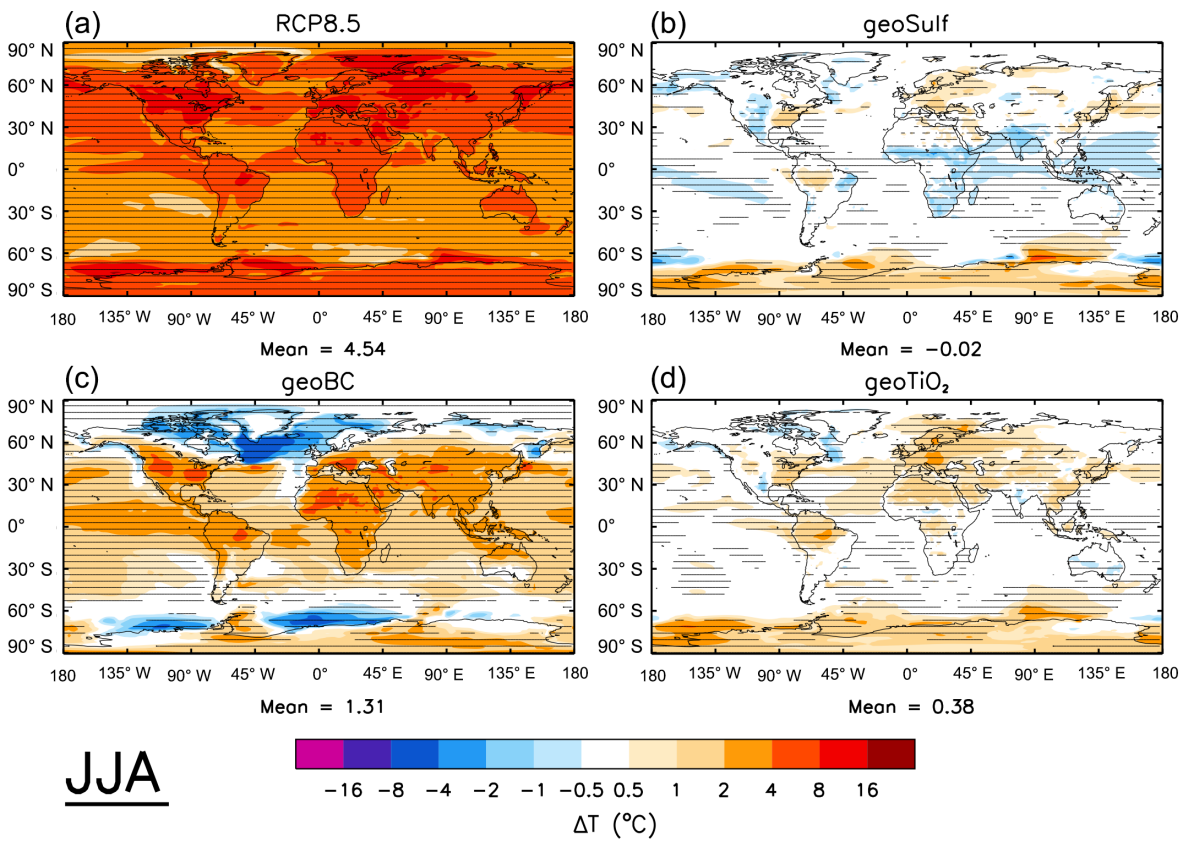

(e) $\quad$ RCP8.5
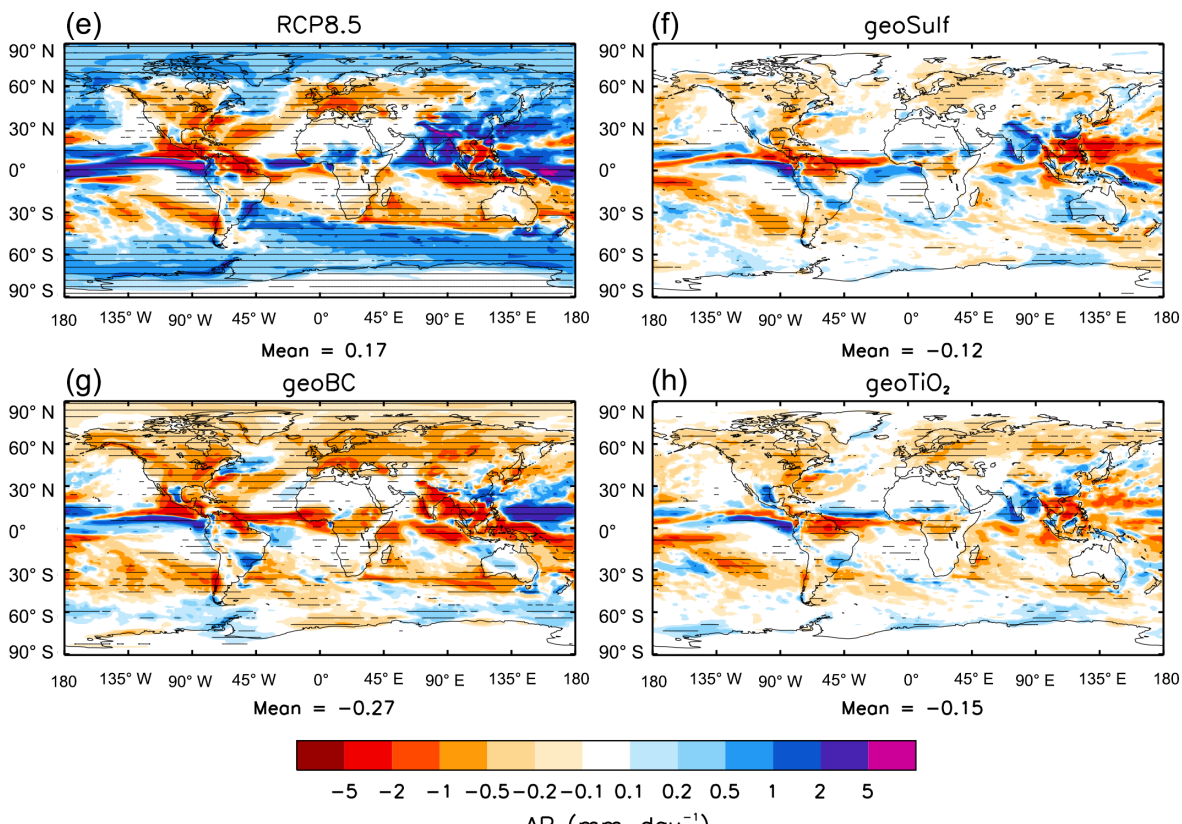

$\Delta P\left(\mathrm{~mm}\right.$ day $\left.^{-1}\right)$

Figure 7. JJA near-surface air temperature (top) and precipitation rate (bottom) anomalies with respect to HIST.

sponse to SAI, and adopt a similar metric to that used by Ferraro et al. (2011) to determine the stratospheric temperature gradient. Explicitly, we determine the difference in temperature between $20^{\circ} \mathrm{N}-20^{\circ} \mathrm{S}$ (Tropics) and $50-90^{\circ} \mathrm{N}$ (North Pole) at $17-22 \mathrm{~km}$ altitude in the DJF season. Using this metric, the change in temperature gradients for geoBC, geoSulf and geoTiO 2 are $+10.4,+7$, and $+10.1^{\circ} \mathrm{C}$, respectively, indicating a steeper temperature gradient between the tropics and poles. Additionally, Fig. 11 shows the $50 \mathrm{hPa}$ DJF geopotential height anomalies over the Arctic for RCP8.5 and the three SAI experiments. The negative geopotential height anomaly centered over the North Pole in all the SAI experiments is indicative of a strengthened polar night jet and a positive Arctic Oscillation phase (Stenchikov et al., 2002). The DJF zonal-mean zonal-wind anomaly (Fig. S9) substantiates our inference of a strengthened polar-night jet under SAI, with increased zonal wind speeds at $65^{\circ} \mathrm{N} 40 \mathrm{~km}^{-1}$ altitude of 62,17 , and $37 \mathrm{~m} \mathrm{~s}^{-1}$ for geoBC, geoSulf, and geoTiO ${ }_{2}$, respectively. 
(a)

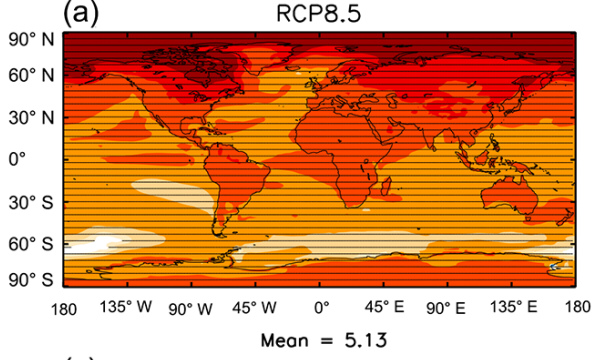

(c)

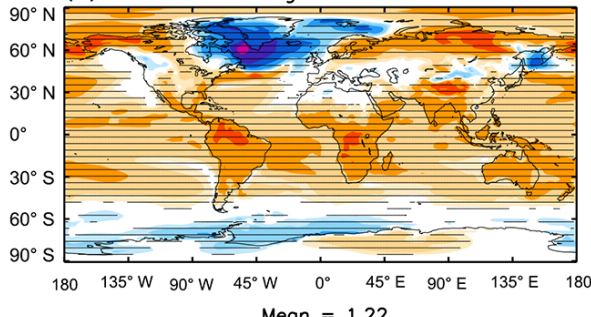

Mean $=1.22$ (b)

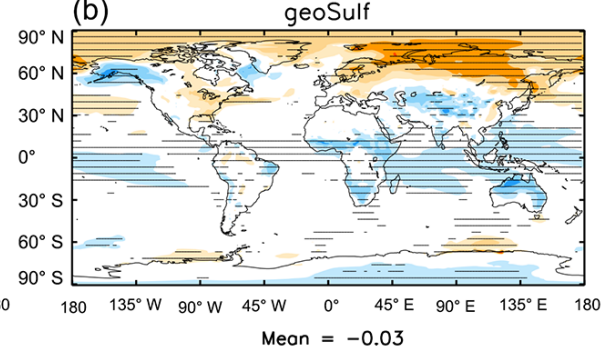

(d)

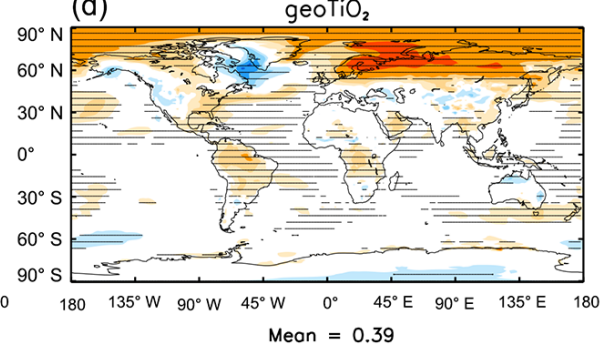

Mean $=0.39$

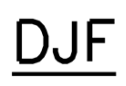

(e)

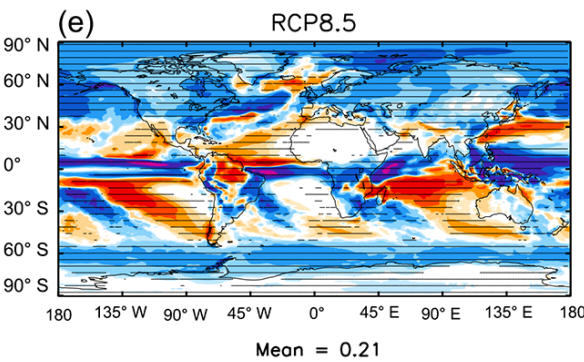

(g)

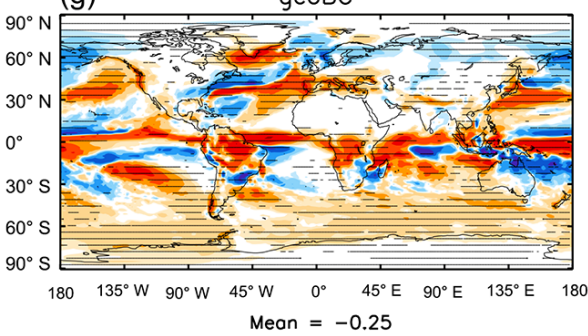

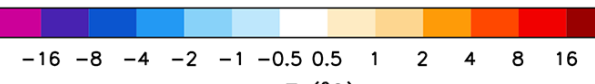

$\triangle \mathrm{T}\left({ }^{\circ} \mathrm{C}\right)$

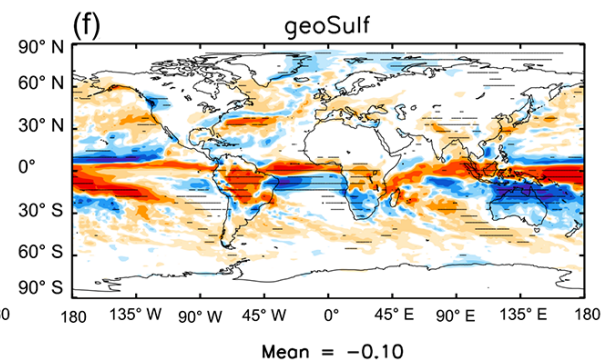

(h)

geoTiO $_{2}$
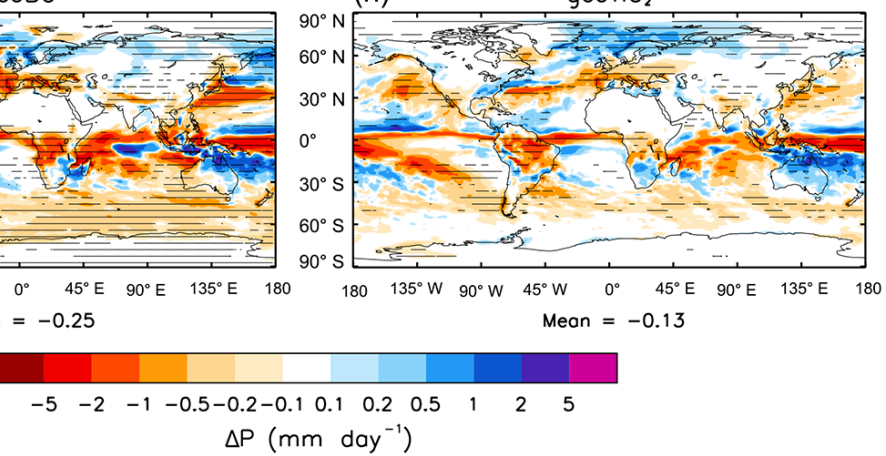

Figure 8. DJF near-surface air temperature (top) and precipitation rate (bottom) anomalies with respect to HIST.

The Quasi-Biennial Oscillation (QBO) is a periodic change in the equatorial zonal wind pattern in the stratosphere, which fluctuates between easterly and westerly shear phases (Baldwin et al., 2001). Aquila et al. (2014) showed that radiative heating in the aerosol layer could prolong the westerly-phase of the QBO (where the phase is defined at $40 \mathrm{hPa}$ ) by enhancing the residual-mean upwelling motion and strengthening the westerly winds. HadGEM2-CCS includes a non-orographic gravity wave scheme that permits the model to internally generate a $\mathrm{QBO}$ and is therefore ca- pable of assessing QBO changes (The HadGEM2 Development Team, 2011). The average QBO period for the HIST-era ensemble is 27 months (Fig. S10) which agrees closely with observations (e.g., Baldwin et al., 2001). Figure 12 shows the 2090s QBO time series for one ensemble member of the RCP8.5 and SAI experiments (Figs. S11a, b show the QBO time series for the other two ensemble members). The average QBO periods for this timespan, which are determined using all three ensemble members, are 20 months for RCP8.5, 31 months for geoSulf and 36 months for geoTiO 2 . 
(a) RCP8.5: Sea-Ice DJF

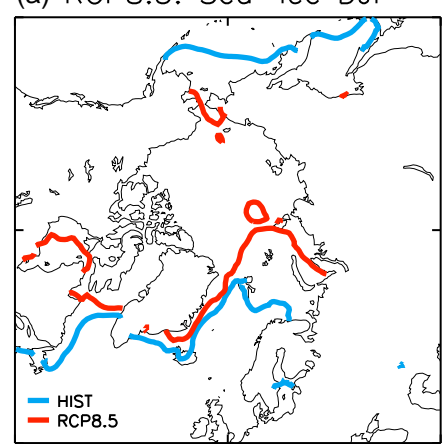

$\Delta=-11.00$ million $\mathrm{km}^{2}$

(c) geoBC: Sea-lce DJF

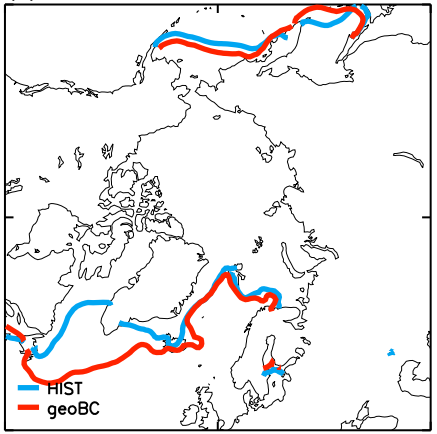

$\Delta=+1.72$ million $\mathrm{km}^{2}$ (b) geoSulf: Sea-lce DJF

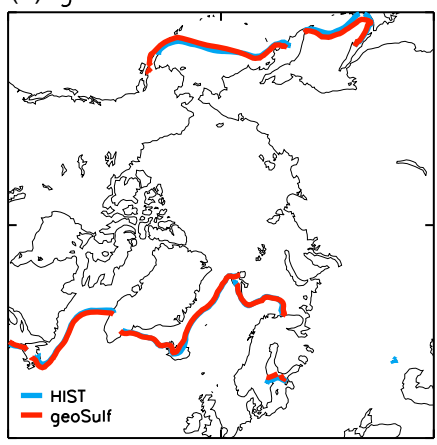

$\Delta=-0.15$ million $\mathrm{km}^{2}$

(d) geoTiO $_{2}:$ Sea-lce DJF

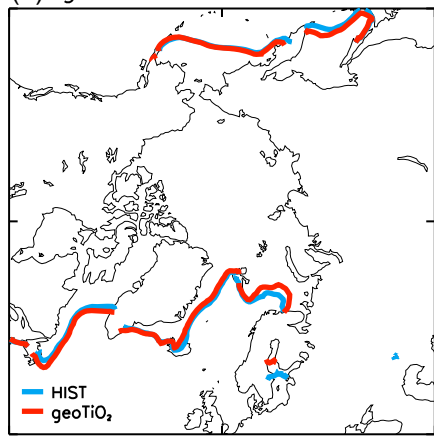

$\Delta=-0.39$ million $\mathrm{km}^{2}$

Figure 9. DJF Northern Hemisphere sea-ice edge plotted with the HIST extent.

For geoBC, no QBO-like oscillation can be detected in the 10 -year time span, suggesting a persistent westerly-phase such as observed by Aquila et al. (2014) in their $5 \mathrm{Tg}$ $\left(\mathrm{SO}_{2}\right) \mathrm{yr}^{-1}$ injection scenario $\left(G_{5}^{22-25 \mathrm{~km}}\right)$ scenario. In their HadGEM2-CC simulations, Kawatani and Hamilton (2013) also observed a decline in the QBO period for the RCP8.5 scenario, although they were unable to provide a reason for this. A robust inference from this work is that the magnitude of SAI's impact on stratospheric zonal winds correlates with the magnitude of the stratospheric warming.

\section{Discussion}

In this work, we have assessed the climatic impacts of sulfate, black carbon and titania-injection against a baseline RCP8.5 scenario, by comparing the 2090s climate with a simulated historical period. We have shown that, although the distribution of climate changes are similar for the three SAI scenarios, the magnitude of the changes differ, for instance BC produces a substantially greater stratospheric warming signal with concomitantly greater changes to stratospheric dynamics. The severity of the stratospheric temperature changes effectively excludes BC from being a viable option for geoengineering. Additionally, we have shown that producing an equivalent top of the atmosphere radiative perturbation with an SW-absorbing aerosol such as BC (or to a lesser extent titania) compared to a SW-scattering aerosol such as sulfate, induces a comparatively greater SW forcing at the surface. Bala et al. (2008) showed that reduced latent heat fluxes compensate for the SW reduction at the surface, instigating a deceleration of the hydrological cycle that is proportional to the magnitude of the SW reduction. This explains the comparatively greater precipitation reduction exhibited by geoBC in Figs. 6-8. Our results complement Niemeier et al. (2013), who showed that an LW-absorbing sulfate layer would produce a greater hydrological perturbation per TOA SW forcing than a simple solar irradiance reduction scenario. The geoBC scenario displays greater cooling at high-latitudes than the geoSulf and geoTiO 2 scenarios (Figs. 6-8), which comparatively exhibit a net tropical cooling. This raises the question of whether a combination of aerosols could potentially be injected to produce a latitudinally uniform cooling if necessary. Although SAI with sulfate and titania effectively maintains the regional distribution of temperature at HIST levels, with a slight residual warming at high latitudes, the hydrological cycle decelerates substantially in all SAI scenarios which is exemplified by a global-mean reduction in precipitation. However, annual-minimum sea-ice ex- 
(a)

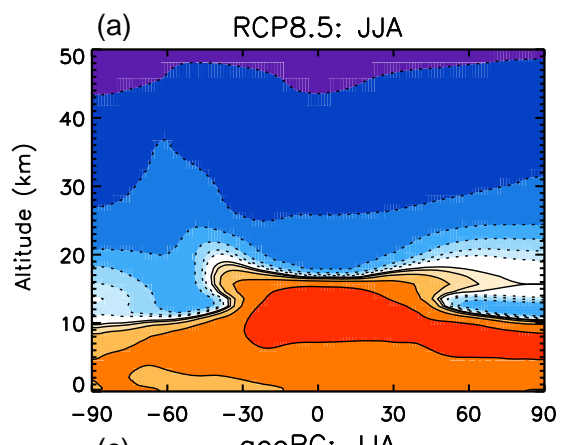

(c)

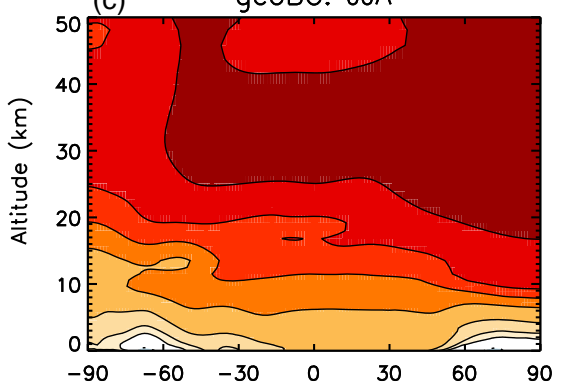

(e)
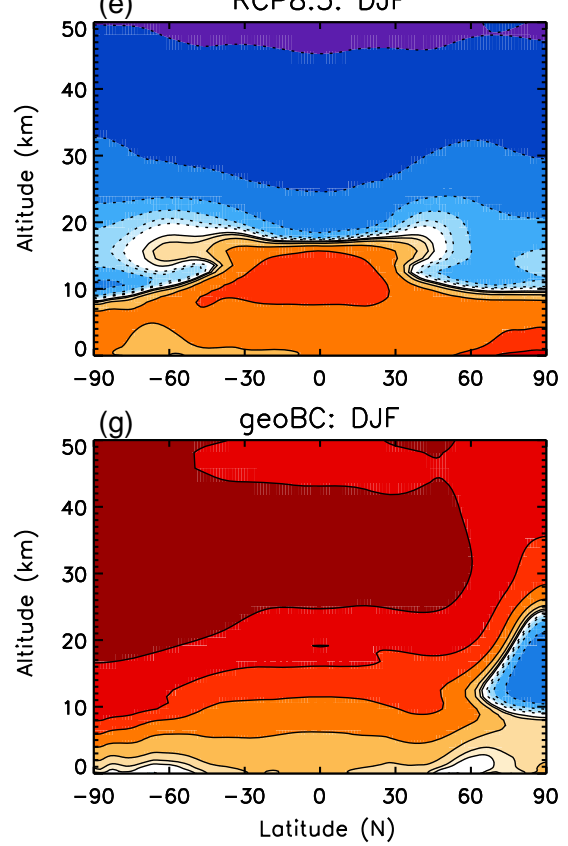

(b) geoSulf: JJA

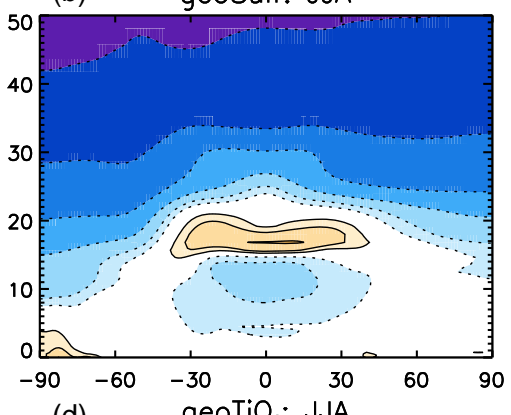

(d)
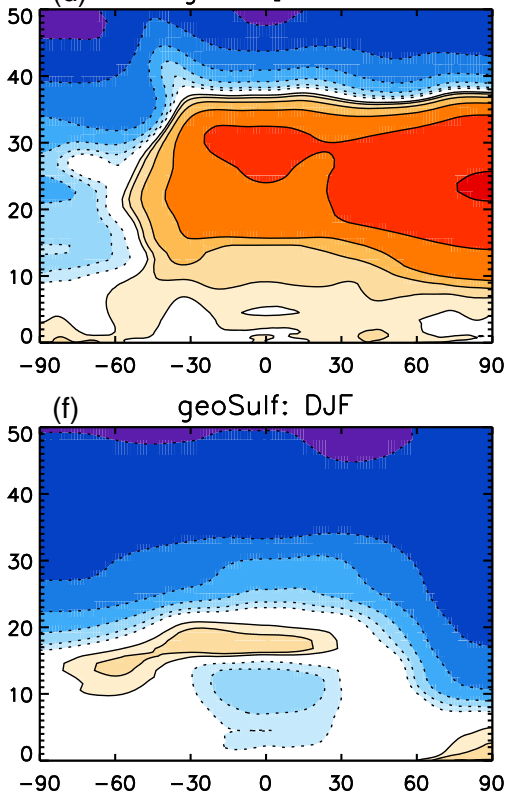

(h) $\quad$ geoTiO $_{2}:$ DJF

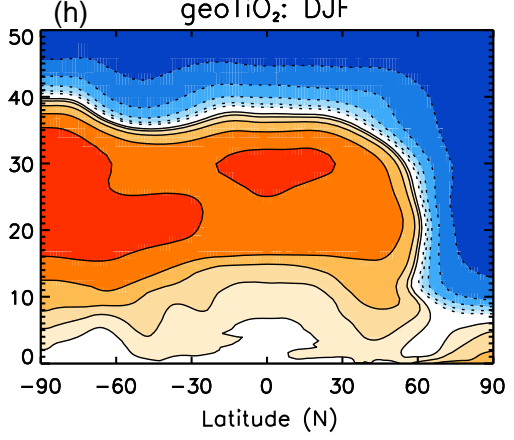

$\begin{array}{llllllllllllll}-32 & -16 & -8 & -4 & -2 & -1 & -0.5 & 0.5 & 1 & 2 & 4 & 8 & 16 & 32\end{array}$

$\Delta \mathrm{T}\left({ }^{\circ} \mathrm{C}\right)$

Figure 10. JJA (top) and DJF (bottom) zonal-mean temperature anomaly with altitude, with respect to HIST.

tent in both hemispheres and global-mean thermosteric sealevel (Fig. S12) are almost entirely maintained at HIST levels for all SAI scenarios. The results of our Antarctic sea-ice extent anomalies are comparable to McCusker et al. (2015). In particular, both their Fig. 2 and our Fig. S7 show limited spatial retraction of sea-ice in the sulfate scenario. We have used the same criterion as McCusker for determining which gridcells contain sea-ice (sea-ice fraction of $>15 \%$ ), which aids in the comparison. Additionally, both our results and McCusker's show that SAI can reduce Antarctic temperatures substantially (their Fig. 2, our Fig. 6) compared to the RCP8.5 climate.

We find that sulfate induces less stratospheric warming than titania. In contrast, Ferraro et al. (2011) found that the 

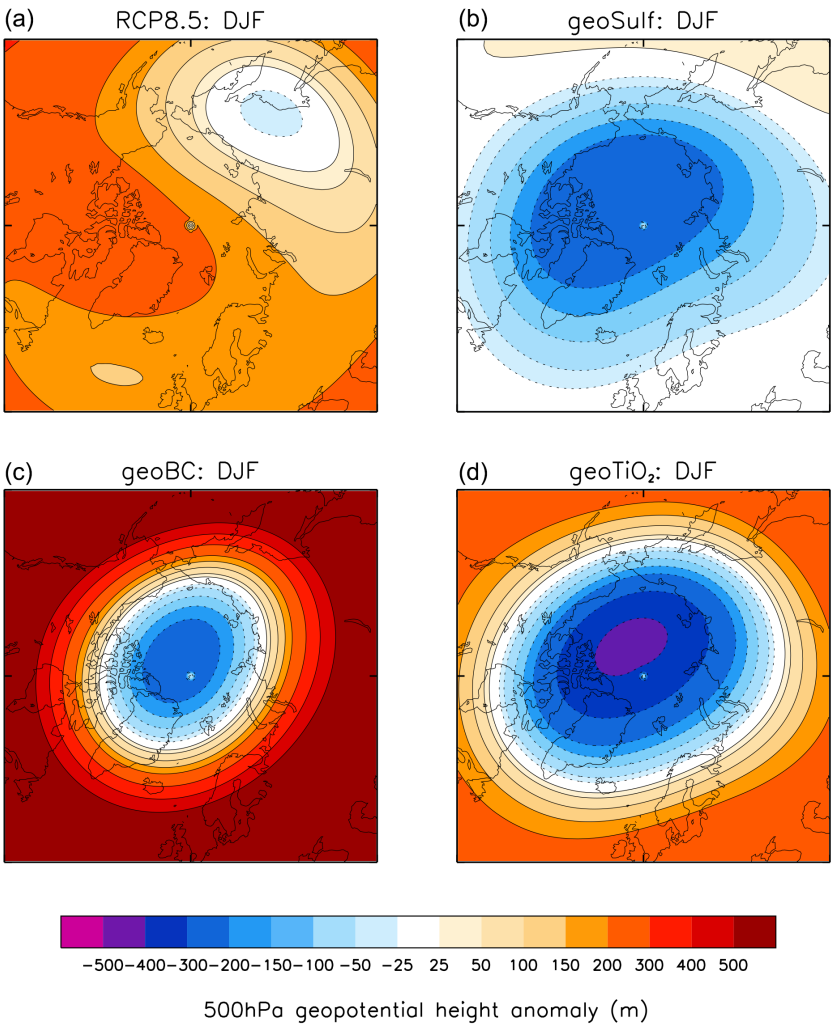

Figure 11. DJF $50 \mathrm{hPa}$ geopotential height anomaly.

peak stratospheric warming for titania was approximately a third of that from sulfate. Although the different climatologies, model configurations, and aerosol spatial distributions will contribute to the difference in stratospheric temperature adjustment between our and Ferraro's work, the primary reason for the disparity is likely to be the aerosol size distributions. Our titania is smaller (median radius $=0.045 \mathrm{com}$ pared to $0.1 \mu \mathrm{m}$ for Ferraro et al., 2011) and therefore scatters and absorbs SW more efficiently, producing a greater localized "solar" warming. Their sulfate distribution contains a larger spread ( $\sigma=2.0$ for Ferraro et al. (2011) compared to $\sigma=1.25$ here), resulting in more coarse-mode particles and greater LW absorption. This disparity highlights the sensitivity of climatic effects to the specified aerosol size distribution. On a separate note, Ferraro et al. (2011) neglected to alter the titania density component in the calculation of their aerosol mass and specific optical properties (A. Ferraro, personal communication, 2016). The density that they used for titania of $1600 \mathrm{~kg} \mathrm{~m}^{-3}$ is appropriate for sulfate, but should have been altered to $\sim 4000 \mathrm{~kg} \mathrm{~m}^{-3}$ for titania. Therefore, their titania aerosol burden should be multiplied by 2.5 to give $7.5 \mathrm{Tg}$, and their optical coefficients divided by 2.5 , to obtain appropriate values.

It is important to note that the climate impacts described in Sect. 4 are dependent on the optical properties of the aerosol, which are further dependent on the aerosol particle's size, shape, and composition (e.g., Kravitz et al., 2012). In this investigation, the dry-mode size distribution of the aerosol species is held constant and hygroscopic growth is not represented in the BC and titania schemes, nor are the effects of internal mixing represented. Observations have shown that fresh $\mathrm{BC}$ aerosol is predominantly hydrophobic, but the uptake of soluble particulates (e.g., secondary organics) results in increased hygroscopicity (Liu et al., 2013). Mineral dust, which contains $1-10 \%$ titania by mass (Ndour et al., 2008), exhibits low hygroscopicity for radii $<0.1$ and similar growth to equivalently sized sulfate aerosol thereafter (Koehler et al., 2009). Although the historical stratospheric water vapor content is low ( $\sim 4.2 \mathrm{ppmv}$ in the tropical lower stratosphere during the HIST period), aerosol-induced stratospheric warming in the TTL would increase the specific humidity of air entering the stratosphere, therefore impacting hygroscopic growth. The injection of aerosol into pre-existing aerosol layers would lead to larger particles through coagulation and condensation, which would further alter the aerosol's optical and physical properties. The actual size of the aerosol in an SAI scheme would therefore depend on the injection strategy (e.g., location and season) and the size and composition of the injected species (e.g., Carslaw and Kärcher, 2006; Heckendorn et al., 2009). Recent research from Heckendorn et al. (2009), Pierce et al. (2010), English et al. (2012), and Weisenstein et al. (2015) has highlighted the importance of representing aerosol growth in SAI simulations. Incorporating aerosol microphysics would result in a better representation of the aerosol's optical properties; this is particularly important for solid aerosols that form chain-like fractals. However, it is also important that the model's climatology is able to respond to radiative changes induced by the aerosol. A more detailed assessment would couple a 3-D GCM with a detailed aerosol microphysics module, but such experiments over the centennial timescales of this work are currently too computationally expensive. A detailed assessment of the aerosol microphysics for sulfate, $\mathrm{BC}$, and titania injection is therefore not within the scope of this paper, but presents an important subject for future work.

The climatic impacts described in Sect. 4 are specific to geoengineering against a baseline RCP8.5 scenario. If instead we had used a middle-of-the-road GHG-concentrations scenario such as RCP4.5 (Taylor et al., 2012), as used in the first tier of GeoMIP scenarios (Kravitz et al., 2011), then less aerosol-injection would be needed to obtain TOA-Imb $=0$ and therefore the aerosol deposition rates and atmospheric mass concentrations would be less than those reported in Sect. 4. One would expect that the magnitude of stratospheric temperature changes (Fig. 8) and therefore zonal-mean zonal wind changes (Fig. 12) would be much less for each of the aerosols, possibly confounding the conclusions given here relating to their comparative efficacy. An estimate for the amount of SAI required for RCP4.5 can be garnered from integrating the temperature anomalies for RCP8.5 and RCP4.5 for the period 2020-2100. The ratio of the integrated tem- 


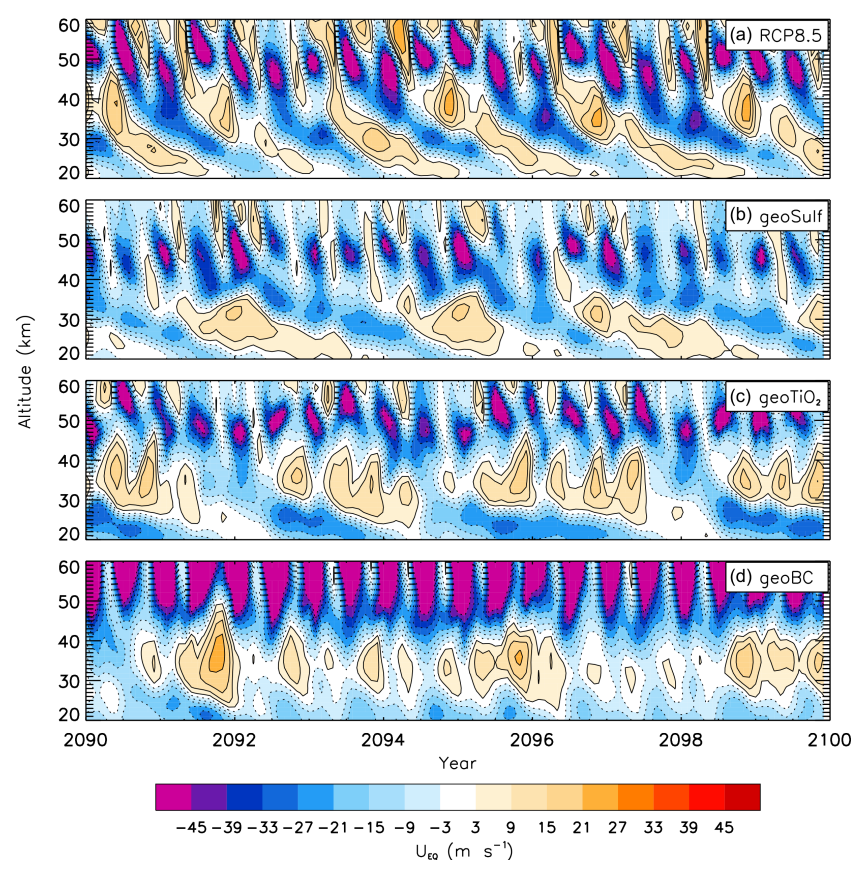

Figure 12. Time series of equatorial $\left(5^{\circ} \mathrm{S}-5^{\circ} \mathrm{N}\right)$ zonal-mean zonal wind profile.

perature anomalies for RCP4.5 to RCP8.5 is 0.43 , hence we can assume that the injection rates required for RCP4.5 are $\sim 0.43$ of those for RCP8.5, producing a climate perturbation $\sim 0.43$ times as great. A further set of simulations, which instead utilise RCP4.5 as the baseline scenario, would be required to test this hypothesis.

We have used prescribed ozone fields in these simulations because representing stratospheric chemistry is prohibitively computationally expensive for the multiple centennial simulations performed here (The HadGEM2 development team, 2011). Kravitz et al. (2012) showed in their SmR scenario that $\mathrm{BC}$ injection could potentially result in global ozone depletion of $>50 \%$, therefore the chemistry changes in SAI could potentially exceed the importance of the physical changes in terms of climatic impacts (e.g., UV radiation at the surface). Tilmes et al. (2012) showed that SWscattering by geoengineered sulfate could potentially compensate for ozone-loss by back-scattering UV radiation in the tropics, but that this effect was insufficiently compensatory at high latitudes. Their result was scenario-dependent; ozone loss due to heterogeneous chemistry is enhanced for smaller particles and in the presence of higher free-radical concentrations. Therefore, additional research is needed in order to understand the effects on atmospheric chemistry of injecting alternative aerosols. This work has already been started for titania by Tang et al. (2014).

Another important aspect of SAI which is comparatively under-researched is the potential for impacts on human health. Aerosol concentrations in the air near the surface are of interest because of potential human respiratory impacts (Robock, 2008). For instance, the USA's National Institute for Occupational Safety and Health (NIOSH) recommends maximum exposure limits of $0.3 \mathrm{mg} \mathrm{m}^{-3}$ for ultrafine titania particles (radius $<0.05 \mu \mathrm{m}$ ) and $2.4 \mathrm{mg} \mathrm{m}^{-3}$ for fine particles (radius < $1.5 \mu \mathrm{m}$ ) (Dankovic et al., 2011). After undergoing coagulation and aging in the atmosphere, it is likely that the second exposure limit is more applicable to this work. In our simulations, the maximum 2090s near-surface air concentration of titania (e.g., Fig. 4) for land regions between $60^{\circ} \mathrm{S}$ and $60^{\circ} \mathrm{N}$ is $254 \mathrm{ng} \mathrm{m}^{-3}$, which is of the order of $10^{2}$ less than the NIOSH "fine-particle" exposure limit. The equivalent maximum concentration anomalies of $\mathrm{BC}$ in geoBC and $\mathrm{SO}_{4}$ in geoSulf are 10 and $1851 \mathrm{ng} \mathrm{m}^{-3}$, respectively. More work is needed to assess the potential impacts of SAI on air quality and human health.

Another thus far unmentioned aspect of this research is the potential for surface albedo modification by aerosol deposition. In particular, $\mathrm{BC}$ deposition on snow reduces the snow albedo through enhanced snow-melt and the coarsening of snow grains, which results in amplified high-latitude warming (Marks and King, 2013). HadGEM2-CCS does not include the BC-on-snow feedback; therefore we estimate it by comparing the deposition rates for 2090s geoBC with the historical period. Jiao et al. (2014) report that the simulated annual mean Arctic $\left(>60^{\circ} \mathrm{N}\right)$ BC deposition for the 2006 2009 period ranges from 13 to $35 \times 10^{7} \mathrm{~kg} \mathrm{yr}^{-1}$ for the AEROCOM Phase II models. The annual mean Arctic BC deposition for the 2006-2009 period from our HadGEM2-CCS simulations is $23 \times 10^{7} \mathrm{~kg} \mathrm{yr}^{-1}$, which is within the AERO$\mathrm{COM}$ range. The annual mean Arctic $\mathrm{BC}$ deposition anomaly for the 2090s period in geoBC is $19.6 \times 10^{7} \mathrm{~kg} \mathrm{yr}^{-1}$. Therefore, the effects of dirty snow in such an SAI scenario would likely be significant, which would have impacts on the distribution of temperature, particularly at high latitudes, potentially confounding some of our conclusions. Although we have emphasized this issue with respect to $\mathrm{BC}$, it is important to note that any particle that absorbs SW radiation will instil this forcing. Therefore, titania, which has a non-unitary single scattering albedo at short wavelengths, will also cause snow-grain coarsening and snow-melt by absorbing solar radiation and warming the top layer of the snow pack.

This research has highlighted potential climate impacts of injecting various stratospheric aerosols in order to ameliorate global warming. However, further research is needed to further assess the climatic impacts of stratospheric aerosol injection such as the impacts on ozone. Whilst research indicates that SAI is capable of averting certain climate changes such as surface-warming, SAI provides no amelioration for other climate impacts, such as ocean acidification. It is therefore important to note that the safest possible solution to avoiding the sort of climate change instantiated by, e.g., Fig. 6a of this report is to effectively mitigate greenhouse-gas emissions. 


\section{Data sets}

Data used to generate figures, graphs, plots and tables are freely available via contacting the lead author: aj247@exeter.ac.uk.

\section{The Supplement related to this article is available online at doi:10.5194/acp-16-2843-2016-supplement.}

Author contributions. Anthony C. Jones designed the experiments, performed the simulations, analyzed the data, and wrote the manuscript with guidance and advice from James M. Haywood and Andy Jones.

Acknowledgements. The authors would like to thank Valentina Aquila for supplying AVHRR and SAGE data, and to Peter Cox, Angus Ferraro, David Keith and Alan Robock for helpful discussions. We also thank two anonymous reviewers and John Dykema for their comments and suggestions. Anthony C. Jones was supported by a Met Office/NERC CASE (ref. 580009183) $\mathrm{PhD}$ studentship; James M. Haywood and Andy Jones were supported by the Joint UK DECC/Defra Met Office Hadley Centre Climate Programme (GA01101).

Edited by: B. Kravitz

\section{References}

Aquila, V., Oman, L. D., Stolarski, R. S., Colarco, P. R., and Newman, P. A.: Dispersion of the volcanic sulfate cloud from a Mount Pinatubo-like eruption, J. Geophys. Res., 117, D06216, doi:10.1029/2011JD016968, 2012.

Aquila, V., Garfinkel, C. I., Newman, P. A., Oman, L. D., and Waugh, D. W.: Modifications of the quasi-biennial oscillation by a geoengineering perturbation of the stratospheric aerosol layer, Geophys. Res. Lett., 41, 1738-1744, 2014.

Bala, G., Duffy, P. B., and Taylor, K. E.: Impact of geoengineering schemes on the global hydrological cycle, P. Natl. Acad. Sci. USA, 105, 7664-7669, 2008.

Baldwin, M. P., Gray, L. J., Dunkerton, T. J., Hamilton, K., Haynes, P. H., Randel, W. J., Holton, J. R., Alexander, M. J., Hirota, I., Horinouchi, T., Jones, D. B. A., Kinnersley, J. S., Marquardt, C., Sato, K., and Takahashi, M.: The quasi-biennial oscillation, Rev. Geophys., 39, 179-229, 2001.

Bellouin, N., Boucher, O., Haywood, J., Johnson, C., Jones, A., Rae, J., and Woodward, S.: Improved representation of aerosols for HadGEM2, Hadley Centre technical note 73, Hadley Centre, Met Office, Exeter, UK, available at: http://www.metoffice.gov. uk/media/pdf/8/f/HCTN_73.pdf, 42 pp., 2007.

Bellouin, N., Rae, J., Johnson, C., Haywood, J., Jones, A., and Boucher, O.: Aerosol forcing in the Hadley Centre CMIP5 simulations by HadGEM2-ES and the role of ammonium nitrate, J. Geophys. Res., 116, D20206, doi:10.1029/2011JD016074, 2011.
Berdahl, M., Robock, A., Ji, D., Moore, J. C., Jones, A., Kravitz, B., and Watanabe, S.: Arctic cryosphere response in the Geoengineering Model Intercomparison Project G3 and G4 scenarios, J. Geophys. Res.-Atmos., 119, 1308-1321, 2014.

Carslaw, K. C. and Kärcher, B.: Stratospheric aerosol processes, in: Assessment of Stratospheric Aerosol Properties, edited by: Thomason, L. and Peter, T., WCRP 124, WMO/TD 1295, SPARC Rep. 4, World. Meteorol. Organ., Geneva, Switzerland, 2006.

Collins, M., Knutti, R., Arblaster, J., Dufresne, J.-L., Fichefet, T., Friedlingstein, P., Gao, X., Gutowski, W. J., Johns, T., Krinner, G., Shongwe, M., Tebaldi, C., Weaver, A. J., and Wehner, M.: Long-term Climate Change: Projections, Commitments and Irreversibility, in: Climate Change 2013: The Physical Science Basis. Contribution of Working Group I to the Fifth Assessment Report of the Intergovernmental Panel on Climate Change, edited by: Stocker, T. F., Qin, D., Plattner, G.-K., Tignor, M., Allen, S. K., Boschung, J., Nauels, A., Xia, Y., Bex, V., and Midgley, P. M., Cambridge University Press, Cambridge, United Kingdom and New York, NY, USA, 2013.

Crutzen, P.: Albedo Enhancement by Stratospheric Sulfur Injections: A Contribution to Resolve a Policy Dilemma?, Climate Change, 77, 211-220, 2006.

d'Almeida, G. A., Koepke, P., and Shettle, E. P.: Atmospheric aerosols: global climatology and radiative characteristics, A Deepak Publishing, Hampton, USA, 1991.

Dankovic, D., Kuempel, E., Geraci, C., Gilbert, S., Rice, F., Schulte, P., Smith, R., Sofge, C., Wheeler, M., Lentz, T. J., Zumwalde, R., Maynard, A., Attfield, M., Pinheiro, G., Ruder, A., Hubbs, A., Ahlers, H., Lynch, D., Toraason, M., and Vallyathan, V.: Current intelligence bulletin 63: occupational exposure to titanium dioxide, Cincinnati, OH: US Department of Health and Human Services, Public Health Service, Centers for Disease Control and Prevention, National Institute for Occupational Safety and Health, DHHS (NIOSH) Publication No. 2011-160, 1-119, 2011.

Deepak, A. and Gerber, H. E. (Eds.): Report of the experts meeting on aerosols and their climatic effects (Williamsburg, Virginia, March 1983), Rep. WCP-55, World Clim. Programme, World Meteorol. Organ., Geneva, 1983.

Deshler, T. and Anderson-Sprecher, R.: Non-volcanic stratospheric aerosol trends: 1971-2004, in: Assessment of Stratospheric Aerosol Properties, edited by: Thomason, L. and Peter, T., WCRP 124, WMO/TD 1295, SPARC Rep. 4, World Meteorolo. Organ., Geneva, Switzerland, 2006.

Dessler, A. E., Schoeberl, M. R., Wang, T., Davis, S. M., and Rosenlof, K. H.: Stratospheric water vapor feedback, Proc. Natl. Acad. Sci. USA, 110, 18087-18091, 2013.

Dhomse, S. S., Emmerson, K. M., Mann, G. W., Bellouin, N., Carslaw, K. S., Chipperfield, M. P., Hommel, R., Abraham, N. L., Telford, P., Braesicke, P., Dalvi, M., Johnson, C. E., O'Connor, F., Morgenstern, O., Pyle, J. A., Deshler, T., Zawodny, J. M., and Thomason, L. W.: Aerosol microphysics simulations of the Mt. Pinatubo eruption with the UM-UKCA composition-climate model, Atmos. Chem. Phys., 14, 11221-11246, doi:10.5194/acp14-11221-2014, 2014.

Driscoll, S., Bozzo, A., Gray, L. J., Robock, A., and Stenchikov, G.: Coupled Model Intercomparison Project 5 (CMIP5) simula- 
tions of climate following volcanic eruptions, J. Geophys. Res.Atmos., 117, D17105, doi:10.1029/2012JD017607, 2012.

English, J. M., Toon, O. B., and Mills, M. J.: Microphysical simulations of sulfur burdens from stratospheric sulfur geoengineering, Atmos. Chem. Phys., 12, 4775-4793, doi:10.5194/acp-12-47752012, 2012.

Ferraro, A. J., Highwood, E. J., and Charlton-Perez, A. J.: Stratospheric heating by potential geoengineering aerosols, Geophys. Res. Lett., 38, L24706, doi:10.1029/2011GL049761, 2011.

Ferraro, A. J., Highwood, E. J., and Charlton-Perez, A. J.: Weakened tropical circulation and reduced precipitation in response to geoengineering, Environ. Res. Lett., 9, 014001, doi:10.1088/1748-9326/9/1/014001, 2014.

Gettelman, A., Hegglin, M. I., Son, S.-W., Kim, J., Fujiwara, M., Birner, T.,Kremser, S., Rex, M., Añel, J. A., Akiyoshi, H., Austin, J., Bekki, S., Braesike, P.,Brühl, C., Butchart, N., Chipperfield, M., Dameris, M., Dhomse, S., Garny, H.,Hardiman, S. C., Jöckel, P., Kinnison, D. E., Lamarque, J. F., Mancini, E., Marchand, M., Michou, M., Morgenstern, O., Pawson, S., Pitari, G., Plummer, D.,Pyle, J. A., Rozanov, E., Scinocca, J., Shepherd, T. G., Shibata, K., Smale, D., Teyssèdre, H., and Tian, W.: Multimodel assessment of the upper troposphere and lower stratosphere: Tropics and global trends, J. Geophys. Res., 115, D00M08, doi:10.1029/2009JD013638, 2010.

Hansen, J., Sato, M., and Ruedy, R.: Radiative forcing and climate response, J. Geophys. Res., 102, 6831-6864, 1997.

Haywood, J. M., Jones, A., Clarisse, L., Bourassa, A., Barnes, J., Telford, P., Bellouin N., Boucher, O., Agnew, P., Clerbaux, C., Coheur, P., Degenstein, D., and Braesicke, P.: Observations of the eruption of the Sarychev volcano and simulations using the HadGEM2 climate model, J. Geophys. Res., 115, D21212, doi:10.1029/2010JD014447, 2010.

Haywood, J. M., Bellouin, N., Jones, A., Boucher, O., Wild, M., and Shine, K. P.: The roles of aerosol, water vapor and cloud in future global dimming/brightening, J. Geophys. Res., 116, D20203, doi:10.1029/2011JD016000, 2011.

Haywood, J. M., Jones, A., Bellouin, N., and Stephenson, D.: Asymmetric forcing from stratospheric aerosols impacts Sahelian rainfall, Nature Climate Change, 3, 660-665, 2013.

Heckendorn, P., Weisenstein, D., Fueglistaler, S., Luo, B. P., Rozanov, E., Schraner, M., Thomason, L. W., and Peter, T.: The impact of geoengineering aerosols on stratospheric temperature and ozone, Environ. Res. Lett., 4, 045108, doi:10.1088/17489326/4/4/045108, 2009.

Illingworth, A. J., Barker, H. W., Beljaars, A., Ceccaldi, M., Chepfer, H., Clerbaux, N., Cole, J., Delanoë, J., Domenech, C., Donovan, D. P., Fukuda, S., Hirakata, M., Hogan, R. J., Huenerbein, A., Kollias, P., Kubota, T., Nakajima, T., Nakajima, T. Y., Nishizawa, T., Ohno, Y., Okamoto, H., Oki, R., Sato, K., Satoh, M., Shephard, M. W., Velázquez-Blázquez, A., Wandinger, U., Wehr, T., and van Zadelhoff, G.-J.: The EarthCARE Satellite: The Next Step Forward in Global Measurements of Clouds, Aerosols, Precipitation, and Radiation, Bull. Amer. Meteor. Soc., 96, 1311-1332. 2015.

International Civil Aviation Organisation (ICAO): Manual of the ICAO Standard Atmosphere: extended to 80 kilometres (262 200 feet), Doc 7488/3, 3rd Edn., 1993.

Jiao, C., Flanner, M. G., Balkanski, Y., Bauer, S. E., Bellouin, N., Berntsen, T. K., Bian, H., Carslaw, K. S., Chin, M., De Luca, N.,
Diehl, T., Ghan, S. J., Iversen, T., Kirkevåg, A., Koch, D., Liu, X., Mann, G. W., Penner, J. E., Pitari, G., Schulz, M., Seland, Ø., Skeie, R. B., Steenrod, S. D., Stier, P., Takemura, T., Tsigaridis, K., van Noije, T., Yun, Y., and Zhang, K.: An AeroCom assessment of black carbon in Arctic snow and sea ice, Atmos. Chem. Phys., 14, 2399-2417, doi:10.5194/acp-14-2399-2014, 2014.

Kawatani, Y. and Hamilton, K.: Weakened stratospheric quasibiennial oscillation driven by increased tropical mean upwelling, Nature, 497, 478-481, 2013.

Kharin, V. V., Zwiers, F. W., Zhang, X., and Wehner, M.: Changes in temperature and precipitation extremes in the CMIP5 ensemble, Climate Change, 119, 345-357, 2013.

Koehler, K. A., Kreidenweis, S. M., DeMott, P. J., Petters, M. D., Prenni, A. J., and Carrico, C. M.: Hygroscopicity and cloud droplet activation of mineral dust aerosol, Geophys. Res. Lett., 36, L08805, doi:10.1029/2009GL037348, 2009.

Kravitz, B., Robock, A., Boucher, O., Schmidt, H., Taylor, K. E., Stenchikov, G., and Schulz, M.: The Geoengineering Model Intercomparison Project (GeoMIP), Atmosph. Sci. Lett., 12, 162167, 2011.

Kravitz, B., Robock, A., Shindell, D. T., and Miller, M. A.: Sensitivity of stratospheric geoengineering with black carbon to aerosol size and altitude of injection, J. Geophys. Res., 117, D09203, doi:10.1029/2011JD017341, 2012.

Kravitz, B., Robock, A., Forster, P. M., Haywood, J. M., Lawrence, M. G., and Schmidt, H.: An overview of the Geoengineering Model Intercomparison Project (GeoMIP), J. Geophys. Res.Atmos., 118, 13103-13107, 2013.

Kravitz, B., Douglas G MacMartin, D. G., Leedal, D. T., Rasch, P. J., and Jarvis, A. J.: Explicit feedback and the management of uncertainty in meeting climate objectives with solar geoengineering, Environ. Res. Lett., 9, 044006, doi:10.1088/17489326/9/4/044006, 2014.

Kravitz, B., Robock, A., Tilmes, S., Boucher, O., English, J. M., Irvine, P. J., Jones, A., Lawrence, M. G., MacCracken, M., Muri, H., Moore, J. C., Niemeier, U., Phipps, S. J., Sillmann, J., Storelvmo, T., Wang, H., and Watanabe, S.: The Geoengineering Model Intercomparison Project Phase 6 (GeoMIP6): simulation design and preliminary results, Geosci. Model Dev., 8, 33793392, doi:10.5194/gmd-8-3379-2015, 2015.

L'Ecuyer, T. S., Beaudoing, H. K., Rodell, M., Olson, W., Lin, B., Kato, S., Clayson, C. A., Wood, E., Sheffield, J., Adler, R., Huffman, G., Bosilovich, M., Gu, G., Robertson, F., Houser, P. R., Chambers, D., Famiglietti, J. S., Fetzer, E., Liu, W. T., Gao, X., Schlosser, C. A., Clark, E., Lettenmaier, D. P., and Hilburn, K.: The Observed State of the Energy Budget in the Early TwentyFirst Century, J. Climate, 28, 8319-8346., 2015.

Liu, D., Allan, J., Whitehead, J., Young, D., Flynn, M., Coe, H., McFiggans, G., Fleming, Z. L., and Bandy, B.: Ambient black carbon particle hygroscopic properties controlled by mixing state and composition, Atmos. Chem. Phys., 13, 2015-2029, doi:10.5194/acp-13-2015-2013, 2013.

Lombardo, K., Colle, B. A., and Zhang, Z.: Evaluation of Historical and Future Cool Season Precipitation over the Eastern United States and Western Atlantic Storm Track Using CMIP5 Models, J. Climate, 28, 451-467, 2015.

MacMartin, D. G., Keith, D. W., Kravitz, B., and Caldeira, K.: Management of trade-offs in geoengineering through optimal 
choice of non-uniform radiative forcing, Nature Climate Change, 3, 365-368, 2013.

MacMartin, D. G., Kravitz, B., Keith, D. W., and Jarvis, A.: Dynamics of the coupled human-climate system resulting from closedloop control of solar geoengineering, Clim. Dynam., 43, 243258,2014

Marks, A. A. and King, M. D.: The effect of snow/sea ice type on the response of albedo and light penetration depth (e-folding depth) to increasing black carbon, The Cryosphere, 8, 16251638, doi:10.5194/tc-8-1625-2014, 2014.

McCusker, K. E., Battisti, D. S., and Bitz, C. M.: Inability of stratospheric sulfate aerosol injections to preserve the West Antarctic Ice Sheet, Geophys. Res. Lett., 42, 4989-4997, doi:10.1002/2015GL064314, 2015.

Meinshausen, M., Smith, S. J., Calvin, K. V., Daniel, J. S., Kainuma, M. L. T., Lamarque, J.-F., Matsumoto, K., Montzka, S. A., Raper, S. C. B., Riahi, K., Thomson, A. M., Velders, G. J. M., and Van Vuuren, D.: The RCP Greenhouse Gas Concentrations and their Extension from 1765 to 2300, Climate Change (Special Issue), doi:10.1007/s10584-011-0156-z, 2011.

Muller, C. J. and O'Gorman, P. A.: An energetic perspective on the regional response of precipitation to climate change, Nature Climate Change, 1, 266-271, 2011.

Ndour, M., D’Anna, B., George, C., Ka, O., Balkanski, Y., Kleffmann, J., Stemmler, K., and Ammann, M.: Photoenhanced uptake of $\mathrm{NO}_{2}$ on mineral dust: Laboratory experiments and model simulations, Geophys. Res. Lett., 35, L05812, doi:10.1029/2007GL032006, 2008.

Niemeier, U., Schmidt, H., and Timmreck, C.: The dependency of geoengineered sulfate aerosol on the emission strategy, Atmos. Sci. Lett., 12, 189-194, 2011.

Niemeier, U., Schmidt, H., Alterskjær, K., and Kristjánsson, J. E.: Solar irradiance reduction via climate engineering: Impact of different techniques on the energy balance and the hydrological cycle, J. Geophys. Res.-Atmos., 118, 11905-11917, 2013.

Oman, L., Robock, A., Stenchikov, G. L., and Thordarson, T.: High-latitude eruptions cast shadow over the African monsoon and the flow of the Nile, Geophys. Res. Lett., 33, L18711, doi:10.1029/2006GL027665, 2006.

Peters, G. P., Andrew, R. M., Boden, T., Canadell, J. G., Ciais, P., Le Quéré, C., Marland, G., Raupach, M. R., and Wilson, C.: The challenge to keep global warming below $2{ }^{\circ} \mathrm{C}$, Nature Climate Change, 3, 4-6, 2013.

Pierce, J. R., Weisenstein, D. K., Heckendorn, P., Peter, T., and Keith, D. W.: Efficient formation of stratospheric aerosol for climate engineering by emission of condensible vapor from aircraft, Geophys. Res. Lett., 37, L18805, doi:10.1029/2010GL043975, 2010

Pitari, G., Aquila, V., Kravitz, B., Robock, A., Watanabe, S., Cionni, I., De Luca, N., Di Genova, G., Mancini, E., and Tilmes, S.: Stratospheric ozone response to sulfate geoengineering: Results from the Geoengineering Model Intercomparison Project (GeoMIP), J. Geophys. Res.-Atmos., 119, 2629-2653, 2014.

Pithan, F. and Mauritsen, T.: Arctic amplification dominated by temperature feedbacks in contemporary climate models, Nat. Geosci., 7, 181-184, 2014.

Pope, F. D., Braesicke, P., Grainger, R. G., Kalberer, M., Watson, I. M., Davidson, P. J., and Cox, R. A.: Stratospheric aerosol parti- cles and solar-radiation management, Nature Climate Change, 2, 713-719, 2012.

Priestley, K. J., Smith, G. L., Thomas, S., Cooper, D., Lee III, R. B., Walikainen, D., Hess, P., Szewczyk, Z. P., and Wilson, R.: Radiometric Performance of the CERES Earth Radiation Budget Climate Record Sensors on the EOS Aqua and Terra Spacecraft through April 2007, J. Atmos. Oc. Technol., 28, 3-21, 2011.

Pruppacher, H. R. and Klett, J. D.: Microphysics of Clouds and Precipitation, D. Reidel Publishing Company, Dordretch, ISBN: 978-90-277-1106-9, Holland, 1980.

Rasch, P. J., Tilmes, S., Turco, R. P., Robock, A., Oman, L., Chen, C.-C., Stenchikov, G. L., and Garcia, R. R.: An overview of geoengineering of climate using stratospheric sulphate aerosols, Phil. Trans. R. Soc. A, 366, 4007-4037, 2008.

Ribarsky, M. W.: Titanium dioxide, in: Handbook of Optical Constants of Solids, edited by: E. Palik, Academic, Orlando, Fla, 795-804, 1985.

Robock, A., Oman, L., and Stenchikov, G. L.: Regional climate responses to geoengineering with tropical and Arctic $\mathrm{SO}_{2}$ injections, J. Geophys. Res., 113, D16101, doi:10.1029/2008JD010050, 2008.

Schmidt, H., Rast, S., Bunzel, F., Esch, M., Giorgetta, M., Kinne, S., Krismer, T., Stenchikov, G., Timmreck, S., Tomassini, L., and Walz, M.: Response of the middle atmosphere to anthropogenic and natural forcings in the CMIP5 simulations with the Max Planck Institute Earth system model, J. Adv. Model. Earth Syst., 5, 98-116, 2013.

Schoeberl, M. R., Douglass, A. R., Stolarski, R. S., Pawson, S., Strahan, S. E., and Read, W.: Comparison of lower stratospheric tropical mean vertical velocities, J. Geophys. Res., 113, D24109, doi:10.1029/2008JD010221, 2008.

Shepherd, J.: Geoengineering the climate: Science, governance, and uncertainty, Royal Society Policy document 10/09, ISBN: 978-085403-773-5, 82 pp., 2009.

Stenchikov, G., Robock, A., Ramaswamy, V., Schwarzkopf, M. D., Hamilton, K., and Ramachandran, S.: Arctic Oscillation response to the 1991 Mount Pinatubo eruption: Effects of volcanic aerosols and ozone depletion, J. Geophys. Res., 107, 4803, doi:10.1029/2002JD002090, 2002.

Tang, M. J., Telford, P. J., Pope, F. D., Rkiouak, L., Abraham, N. L., Archibald, A. T., Braesicke, P., Pyle, J. A., McGregor, J., Watson, I. M., Cox, R. A., and Kalberer, M.: Heterogeneous reaction of $\mathrm{N}_{2} \mathrm{O}_{5}$ with airborne $\mathrm{TiO}_{2}$ particles and its implication for stratospheric particle injection, Atmos. Chem. Phys., 14, 6035-6048, doi:10.5194/acp-14-6035-2014, 2014.

Taylor, K. E., Stouffer, R. J., and Meehl, G. A.: An Overview of CMIP5 and the Experiment Design, Bull. Amer. Meteor. Soc., 93, 485-498, 2012.

Tegtmeier, S., Kruger, K., Wohltmann, I., Schoellhammer, K., and Rex, M.: Variations of the residual circulation in the Northern Hemispheric winter, J. Geophys. Res., 113, D16109, doi:10.1029/2007JD009518, 2008.

Teller, E., Wood, L., and Hyde, R.: Global Warming and Ice Ages: I. Prospects for Physics-Based Modulation of Global Change, Lawrence Livermore National Laboratory Publication UCRLJC-128715, 18 pp., 1997.

The HadGEM2 Development Team: Martin, G. M., Bellouin, N., Collins, W. J., Culverwell, I. D., Halloran, P.R., Hardiman, S. C., Hinton, T. J., Jones, C. D., McDonald, R. E., McLaren, A. J., 
O'Connor, F. M., Roberts, M. J., Rodriguez, J. M., Woodward, S., Best, M. J., Brooks, M. E., Brown, A. R., Butchart, N., Dearden, C., Derbyshire, S. H., Dharssi, I., Doutriaux-Boucher, M., Edwards, J. M., Falloon, P. D., Gedney, N., Gray, L. J., Hewitt, H. T., Hobson, M., Huddleston, M. R., Hughes, J., Ineson, S., Ingram, W. J., James, P. M., Johns, T. C., Johnson, C. E., Jones, A., Jones, C. P., Joshi, M. M., Keen, A. B., Liddicoat, S., Lock, A. P., Maidens, A. V., Manners, J. C., Milton, S. F., Rae, J. G. L., Ridley, J. K., Sellar, A., Senior, C. A., Totterdell, I. J., Verhoef, A., Vidale, P. L., and Wiltshire, A.: The HadGEM2 family of Met Office Unified Model climate configurations, Geosci. Model Dev., 4, 723-757, doi:10.5194/gmd-4-723-2011, 2011.

Tilmes, S., Garcia, R. R., Kinnison, D. E., Gettelman, A., and Rasch, P. J.: Impact of geoengineered aerosols on the troposphere and stratosphere, J. Geophys. Res., 114, D12305, doi:10.1029/2008JD011420, 2009.

Tilmes, S., Kinnison, D. E., Garcia, R. R., Salawitch, R., Canty, T., Lee-Taylor, J., Madronich, S., and Chance, K.: Impact of very short-lived halogens on stratospheric ozone abundance and UV radiation in a geo-engineered atmosphere, Atmos. Chem. Phys., 12, 10945-10955, doi:10.5194/acp-12-10945-2012, 2012.

Tilmes, S., Fasullo, J., Lamarque, J.-F., Marsh, D. R., Mills, M., Alterskjær, K., Muri, H., Kristjánsson, J. E., Boucher, O., Schulz, M., Cole, J. N. S., Curry, C. L., Jones, A., Haywood, J., Irvine, P. J., Ji, D., Moore, J. C., Karam, D. B., Kravitz, B., Rasch, P. J., Singh, C., Yoon, J.-H., Niemeier, U., Schmidt, H., Robock, A., Yang, S., and Watanabe, S.: The hydrological impact of geoengineering in the Geoengineering Model Intercomparison Project (GeoMIP), J. Geophys. Res.-Atmos., 118, 11036-11058, 2013. von Schuckmann, K., Palmer, M. D., Trenberth, K. E., Cazenave, A., Chambers, D., Champollion, N., Hansen, J., Josey, S. A., Loeb, N., Mathieu, P.-P., Meyssignac, B., and Wild, M.: An imperative to monitor Earth's energy imbalance, Nature Climate Change, 6, 138-144, 2016.

Weisenstein, D. K., Keith, D. W., and Dykema, J. A.: Solar geoengineering using solid aerosol in the stratosphere, Atmos. Chem. Phys., 15, 11835-11859, doi:10.5194/acp-15-11835-2015, 2015.

Yang, H., Zhu, S., and Pan, N.: Studying the Mechanisms of Titanium Dioxide as Ultraviolet-Blocking Additive for Films and Fabrics by an Improved Scheme, J. Appl. Polym. Sci., 92, 32013210, 2004.

Yu, X., Moore, J. C., Cui, X., Rinke, A., Ji, D., Kravitz, B., and Yoon, J.-H.: Impacts, effectiveness and regional inequalities of the GeoMIP G1 to G4 solar radiation management scenarios, Glob. Planet. Change, 129, 10-22, 2015. 